\title{
TLR3 immunity to infection in mice and humans
}

\author{
Shen-Ying Zhang ${ }^{1,2}$, Melina Herman ${ }^{1,2}$, Michael J. Ciancanelli ${ }^{1}$, Rebeca Pérez de Diego ${ }^{2}$, \\ Vanessa Sancho-Shimizu ${ }^{2}$, Laurent Abel ${ }^{1,2}$, and Jean-Laurent Casanova ${ }^{1,2,3}$ \\ ${ }^{1}$ St. Giles Laboratory of Human Genetics of Infectious Diseases, The Rockefeller University, New \\ York, NY 10065, USA \\ ${ }^{2}$ Laboratory of Human Genetics of Infectious Diseases, Institut National de la Santé et de la \\ Recherche Médicale, University Paris Descartes, Necker Medical School, U980, Paris 75015 \\ France, EU \\ ${ }^{3}$ Pediatric Hematology-Immunology Unit, Necker Hospital, Paris 75015, France, EU
}

\begin{abstract}
TLR3 is a receptor for dsRNA, which is generated during most viral infections. However, other cellular processes may also produce dsRNA and there are other receptors for dsRNA. The role of TLR3 in protective immunity to viruses has been investigated in mice and humans with genetically impaired TLR3 responses. TLR3-deficient mice responded to experimental challenge with 16 different viruses in various ways. They were susceptible to eight viruses, normally resistant to three other viruses, and their survival rates were higher than those of wild-type mice following infection with four other viruses. Conflicting results were obtained for the other virus tested. These data are difficult to understand in terms of a simple pattern based on virus structure or tissue tropism. Surprisingly, the known human patients with inborn errors of the TLR3 pathway have remained healthy or developed encephalitis in the course of natural primary infection with HSV-1. These patients display no clear susceptibility to other infections, including viral infections, such as other forms of viral encephalitis and other HSV-1 diseases in particular. This restricted susceptibility to viruses seems to result from impaired TLR3-dependent IFN- $\alpha / \beta$ production by central nervous system (CNS)-resident non-hematopoietic cells infected with HSV-1. These studies neatly illustrate the value of combining genetic studies of experimental infections in mice and natural infections in humans, to elucidate the biological function of host molecules in protective immunity.
\end{abstract}

\section{Introduction}

Like other vertebrate Toll-like receptors (TLRs), TLR3 consists of an extracellular leucinerich repeat (LRR) motif, a transmembrane (TM) domain and an intracellular Toll and IL-1R (TIR) domain [1,2]. A comparison of the LRR and TIR domains of 366 vertebrate TLRs from 96 species, from fish to primates, revealed that the LRR domains of TLR3 and TLR7 are the most highly conserved [3]. Moreover, TLR3 is one of the four human TLRs (TLR3, TLR7, TLR8 and TLR9) that have evolved under the strongest purifying selection throughout human history [4]. These four TLRs are intracellular and are stimulated by nucleic acids [5,6]. TLR3 recognizes dsRNA, an intermediate generated during most viral infections [7]. It was thus thought that TLR3 acted as a sentinel against viruses. Mice

\footnotetext{
Correspondence: Shen-Ying Zhang (shzh289@ rockefeller.edu).

Publisher's Disclaimer: This is a PDF file of an unedited manuscript that has been accepted for publication. As a service to our customers we are providing this early version of the manuscript. The manuscript will undergo copyediting, typesetting, and review of the resulting proof before it is published in its final citable form. Please note that during the production process errors may be discovered which could affect the content, and all legal disclaimers that apply to the journal pertain.
} 
genetically deficient for TLR3 have been engineered and experimentally challenged with various viruses. Surprisingly, TLR3-deficient mice were found to be susceptible to some viruses but normally resistant or even more resistant than the wild type to others [8-11]. Perhaps even more surprisingly, human patients with inborn errors of TLR3 immunity have been shown to suffer from life-threatening childhood herpes simplex virus 1 (HSV-1) encephalitis (HSE) while remaining normally resistant to other common viruses [12-16]. These observations are consistent with the concomitant discovery of other receptors for dsRNA in mice and humans, with less well documented roles in immunity to infection [11,17-19]. Moreover, dsRNA of non viral origin has been shown to trigger TLR3 signaling, raising the intriguing possibility that the continued investigation of TLR3-deficient mice or humans may reveal other phenotypes not necessarily related to viral infections. TLR3 has attracted considerable attention from investigators in fields as diverse as biochemistry, immunology and medicine. We review here current knowledge concerning TLR3, first focusing on TLR3 and its signaling pathway, then reviewing experimental infections in TLR3-deficient mice, and third describing TLR3-deficient humans.

\section{TLR3 and its signaling pathway}

The crystal structure of the human TLR3 ectodomain (ECD) revealed a large, horseshoeshaped solenoid, potentially providing a large surface area for ligand recognition [20,21]. The TLR3-ECD was also thought to be essential for ligand binding-triggered multimerization [20-25]. More recent studies, performed on mouse or human TLR3-ECD, have demonstrated that TLR3-ECDs bind, as dimeric units, to dsRNA oligonucleotides of at least 45 bp in length, and that each TLR3-ECD binds dsRNA at two sites located at opposite ends of the TLR3 'horseshoe'. Intermolecular contacts between the C-terminal domains of two TLR3-ECDs coordinate and stabilize the TLR3 dimer [26-30]. In these models, the assembly of TLR3 as stable dimers on a single dsRNA ligand is necessary for TLR3 signaling [27,30]. The binding of dsRNA to the TLR3-ECD, the affinity of which increases with both buffer acidity and ligand size [23,27], is thus the first key step in TLR3 signaling. It remains unclear whether the natural dsRNA produced during viral infection can actually stimulate TLR3. Nevertheless, it has been shown that the length and structure of dsRNA agonists is important for TLR3 binding and activation [26-31]. Long dsRNAs are more potent inducers of TLR3 signaling than short dsRNAs [23,26-29,31]. Synthetic poly(I:C) is a nonspecific agonist of TLR3, which stimulates this receptor, leading to its robust activation [32]. Cell-endogenous mRNA, which is single-stranded but contains doublestranded regions [33] and is probably released from necrotic cells [34], can activate TLR3. Ultraviolet-damaged cell self noncoding snU1 (small nuclear U1) RNA, which contains stem-loop structures that could form dsRNA, also can activate TLR3 [35]. By contrast, total human cellular RNA cannot activate TLR3 [36], probably due to its high degree of posttranscriptional nucleoside modification.

TLR3 expression has been shown to be relatively broad in mice and humans. The principal TLR3-expressing cells include peripheral leukocytes, such as dendritic cells [37], CD8 ${ }^{+} \mathrm{T}$ cells [38] and NK cells [39], retinal [40], corneal [41], intrahepatic biliary [42,43] and intestinal [44] epithelial cells, keratinocytes [45,46], lung and dermal fibroblasts [12,13,47], vessel endothelial cells [48], hepatocytes [49] and CNS-resident cells, including neurons, oligodendrocytes, astrocytes and microglia [50-54]. Many in vitro studies have shown that the TLR 3 expressed by these cell types are functional, triggering the production of IFN- $\alpha / \beta$, $-\lambda$, and other cytokines in response to poly(I:C) $[12,38,40,52,53,55-59]$. TLR3 is intracellular in most cell types, human lung fibroblasts being the only cells for which TLR3 expression on the cell surface has been reported [47]. In resting cells, TLR3 is located in the endoplasmic reticulum (ER) [5], along with UNC-93B, a transmembrane protein required for the trafficking of TLR3, TLR7, TLR8 and TLR9 from the ER to the endosomal 
compartment [12,60-62]. Upon stimulation with dsRNA, TLR3 interacts with UNC-93B via the transmembrane domains of the two molecules. It then moves to the endosomes [61,62], where it is colocalized with and phosphorylated by tyrosine kinases c-Src [63,64], EGFR [64] and, perhaps, PI3K $[65,66]$. The dimerized, phosphorylated TLR3 is thus primed to trigger downstream signaling.

The TLR3 signaling pathway is mediated exclusively by the TRIF adapter, which is recruited to TLR3 by interaction between the TIR domains of the two molecules [67,68]. Various branches of the signaling pathway emanating from TLR3-TRIF lead to the activation of IRF3, NF- $\mathrm{kB}$ and AP1 [10,69,70], and to the induction of apoptosis through procaspase- 8 activation [71-73]. The signaling molecules involved have been characterized in detail, and this pathway has been shown to culminate in the activation of IRF3 and NF$\kappa \mathrm{B}$, which together induce the production of antiviral IFNs and other cytokines [74] (Figure 1, Table 1). IRF3 activation is mediated by two kinases, TBK1 and IKKe [75,76], which themselves associate with TRIF through a signalosome complex also containing other key molecules, such as NAP1 and TRAF3 [77-79]. The activation of NF- $\kappa$ B is thought to be essentially mediated by RIP1 [80], and probably also by TRAF6 in some cell types [81,82]. RIP1 and TRAF6 subsequently recruit TAB2 [83] and TAK1, which phosphorylates IKKa and IKK $\beta$ [84]. These two kinases and the IKK adaptor protein IKK $\gamma$ (NEMO) form the IKK complex [85]. IKK $\beta$ phosphorylates the NF- $\kappa B$ inhibitor I $\kappa B$, eventually leading to its degradation and the nuclear translocation of NF- $\mathrm{kB}$ [84].

Other molecules appear to be involved in TLR3-IRF3/NF-^B-IFN pathways (Figure 1, Table 1), either as 'positive regulators', such as BS69, TAPE, TRAF2, TANK, TRIL, SINTBAD, TRADD, DDX3X, CaMKII, RAFLIN, GAB1, TRIM21, TRIM56, HMGB, ELMOD2, PELLINO1, SCARA1 and TRIS, which is a splice variant of TRIF [86-106], or as 'negative regulators', such as SHP-2, RIP3, TRAF1, TRAF4, A20, SARM1, PIASy, SIKE, TRIP, TIPE2 and DUBA [65,80,107-116]. Some molecules, such as NEMO [117] and TANK [90,91], have been shown to link the TLR3-IRF3 and TLR3-NF- $\kappa B$ pathways. Our knowledge of TLR3 signaling pathways has been greatly increased by in vitro studies in mouse and human cells, and in vivo studies in animals for a few molecules (Table 1). Recently developed transcriptional, proteomic and computational methods may help to paint a more comprehensive picture of the TLR3 signaling network [14,118-120]. Many of the molecules involved in TLR3 signaling are common to other signaling pathways, even the most upstream molecule, TRIF, which can be recruited by TLR4 [68] and by another cytosolic dsRNA sensor consisting of three RNA helicases, DDX1, DDX21 and DHX36 [121]. The degree of redundancy of most of the individual components of the TLR3responsive pathway in cellular responses to dsRNA has not been assessed in mice or humans, in whom fewer genetic deficiencies have been described.

\section{TLR3-mediated immunity to experimental infection in mice}

At least six strains of TLR3-deficient mice have been challenged with up to 16 viruses, via at least 10 different routes of infection (Table 2). Various phenotypes have been studied in these mice, including the disease phenotype, viral load, and mortality. However, caution is required when comparing these experiments, due to the diversity of the protocols used. In these experimental models, the infectious phenotypes of the TLR3-deficient mice varied greatly, from enhanced susceptibility to enhanced resistance, with respect to the corresponding wild-type (WT) mouse. In terms of mortality, TLR3-deficient mice have been shown to be susceptible to encephalomyocarditis virus (EMCV) [122,123], coxsackievirus group B3 (CVB3) [124,125], CVB4 [126] and poliovirus [127,128]. While EMCV-infected TLR3-deficient mice have a higher viral load in the heart and display lower induction of proinflammatory cytokines and chemokines in the heart than WT mice [122], these mice 
display high viral load in the pancreas and develop diabetes due to impaired IFN- $\alpha / \beta$ responses upon infection with an EMCV strain with a tropism for pancreatic $\beta$ cells [123]. CVB3-challenged TLR3-deficient mice have a high viral load in the heart and acute myocarditis $[124,125]$, which was accompanied by impaired systemic and cardiac IFN- $\gamma$ induction in one study [124]. Similarly, CVB4 infection results in a high viral load in the heart and liver, together with severe cardiac damage and low levels of pro-inflammatory cytokines in the serum in TLR3-deficient mice [126]. The cardiac damage and poor survival of CVB4-infected TLR3-deficient mice can be rescued by the adoptive transfer of macrophages from WT mice, suggesting that these cells are protective. In mice transgenic for the poliovirus receptor, which are permissive to human poliovirus infection, TLR3 plays a key role in the antiviral response to poliovirus infection, with higher viral loads, in various organs, in TLR3-deficient mice than in WT mice [127].

In some other infections, TLR3 deficiency was found not to result in lower survival, but to underlie impaired virus control or high disease scores [9,124,129,130] (Table 2). TLR3deficient mice are hypersusceptible to HSV-2 infection of the CNS, with a significantly higher viral load and disease score than WT mice, probably due to impaired virus-induced IFN- $\beta$ production and virus control in astrocytes [9]. It would be interesting to evaluate the vulnerability of TLR3-deficient mice to intranasal or intracerebral HSV-1 infection of the CNS. However, when TLR3-deficient mice were challenged with HSV-1 by skin infection, high viral loads were detected only at the site of inoculation [129]. TLR3-deficient mice are also susceptible to respiratory syncytial virus (RSV) infection, but to a lesser extent, this infection resulting in a significant increase in mucus production in the airways [130]. TRIFdeficient mice have been challenged with EMCV, CVB3 and poliovirus, and have been shown to have infectious phenotypes similar to those of TLR3-deficient mice. Thus, TRIFdependent pathways other than those mediated by TLR3 do not appear to play a major role in immunity to these viruses $[124,127,128]$. TRIF-deficient $C D 8 \mathrm{a}^{+} / \mathrm{CD} 11 \mathrm{c}^{+}$splenic dendritic cells and macrophages produce low levels of IFN- $\alpha / \beta$ in response to poliovirus infection. By inference, these cells may be responsible for the low levels of IFN- $\alpha / \beta$ production documented in poliovirus-infected TLR3- and TRIF-deficient mice, thereby contributing to poliovirus susceptibility [128].

Intriguingly, the strain of mouse used has a considerable influence over disease outcome and susceptibility to certain viruses (Table 2). TLR3-deficient mice have been found to be susceptible to mouse cytomegalovirus (MCMV) in some experimental conditions [8,131], as shown by lower survival rates, higher viral load in the spleen and the impaired production in vivo of cytokines, including IFN- $\alpha / \beta$ [8]. However, these mice were found to be normally resistant to MCMV in other experimental conditions [131]. The different mouse strains studied, C57BL/6 in the first study and C57BL/6xB129 in the second, may be one of the factors modifying the infectious phenotype in these mice, although other major differences in experimental conditions (such as infection site, the viral dose used for inoculation etc.) may also have played a role in the reported differences. Likewise, different strains of TLR3deficient mice have been shown to display different degrees of susceptibility to Theiler's murine encephalomyelitis virus (TMEV) [132]. A more virulent strain of TMEV causes fatal encephalitis in C57BL/6 TLR3-deficient mice, whereas a less virulent strain of TMEV leads to high viral load in the CNS accompanied by severe CNS demyelination in SJL, but not C57BL/6 TLR3-deficient mice. It has also been suggested that TLR3 signaling in these experimental models may be either protective or pathogenic for the development of TMEVinduced demyelinating disease, depending on whether TLR3 signaling is activated during or before viral infection [132].

Moreover, TLR3-deficient mice are normally resistant to VSV, LCMV and T3 reovirus [131] (Table 2). TLR3-deficient mice display levels of IFN- $\gamma$ production by $\mathrm{CD} 8^{+} \mathrm{T}$ and 
$\mathrm{CD}^{+} \mathrm{T}$ cells in response to VSV and LCMV similar to those in WT mice; they are also similar to WT mice in terms of T3 reovirus-induced injury in the CNS [131]. Remarkably, TLR3-deficient mice appear to be even more resistant to other infections than WT mice, in terms of mortality (Table 2). They display enhanced resistance to influenza virus [133], punta toro virus [134], vaccinia virus [135] and West Nile virus (WNV) [136] infections. Viral load does not appear to underlie disease susceptibility in these infectious models. In some studies, high viral loads have been detected in the periphery (WNV) or in a specific organ (influenza virus in the lung). Conversely, in other studies, low viral loads were detected in the periphery (PTV) or in specific organs (vaccinia virus in the respiratory tract and WNV in the brain). A weak inflammatory response in TLR3-deficient animals might contribute to the low disease severity in these mice. Overall, studies in mice have provided unique insight, through carefully controlled experimental viral infections. However, only one virus (TMEV) has been assessed in direct comparative studies using both different viral strains (low virulence vs high virulence) and different mouse strains (SJL vs C57BL/6). Moreover, some important human-tropic viruses have not been studied in mice (e.g. human hepatitis viruses, varicella zoster virus (VZV), mumps virus, parvovirus), including some viruses for which mice are not permissive (e.g. human hepatitis viruses and VZV).

\section{TLR3-mediated immunity to natural infection in humans}

The first indication that human TLR3 immunity might be important in host defense against viral infection in humans was provided by the discovery of UNC-93B-deficiency in children with HSE, in 2006 [12]. Childhood HSE is a life-threatening complication of primary infection with HSV-1, a common virus that is innocuous in most children [137,138]. HSV-1 is a neurotropic dsDNA virus that produces dsRNA during its replication $[139,140]$. Although rare, HSE is the most common form of sporadic viral encephalitis in Western countries. The pathogenesis of HSE had long remained unclear, until our recent demonstration that some cases of the disease may result from single-gene inborn errors of TLR3-mediated immunity [141]. Two unrelated children with HSE and autosomal recessive (AR) complete UNC-93B deficiency have been identified [12]. TLR3 and TLR7/8/9 signaling was found to be abolished in the patients' fibroblasts and peripheral blood mononuclear cells (PBMCs), respectively. It had been suggested that TLR7-, TLR8- and TLR9-mediated IFN- $\alpha,-\beta$ and $-\lambda$ production was largely redundant in human antiviral immunity, as IRAK-4- and MyD88-deficient patients display impaired responses to TLR7, TLR8 and TLR9 but normal responses to TLR3, and suffer from pneumococcal disease but are resistant to viruses, including HSV-1 [142-146]. Impaired TLR3-triggered, UNC-93Bdependent IFN- $\alpha,-\beta$, or $-\lambda$ immunity may therefore underlie HSE in UNC-93B-deficient patients. Autosomal dominant (AD) and AR TLR3 deficiencies were subsequently identified in other patients with HSE, providing evidence that human TLR3 is involved in host defense against HSV-1 in the CNS during primary infection in childhood $[13,118,147,148]$. The production of IFN- $\beta$ and $-\lambda$ by fibroblasts in response to stimulation with poly(I:C), HSV-1 and vesicular stomatitis virus (VSV) is impaired in TLR3-deficient fibroblasts, as in UNC-93B-deficient fibroblasts. Impaired TLR3 signaling also leads to high levels of viral replication and cell death in fibroblasts from patients following infection with HSV-1 or VSV, providing a plausible hypothesis for the molecular pathogenesis of the disease in the CNS.

The subsequent discovery of AR and AD TRIF deficiencies in children with HSE completely validated the essential role of human TLR3 immunity in anti-HSV-1 defense in the CNS [149]. The TLR3 signaling pathway was found to be impaired in cells from patients with both AR and AD TRIF deficiencies, whereas the TRIF-dependent TLR4 pathway was affected only in patients with AR TRIF deficiency [68]. Interestingly, abnormally weak responses to stimulation of the DExD/H-box helicase pathway [121] have been observed in 
both AR and AD TRIF-deficient fibroblasts. These results demonstrated the importance of TRIF for the TLR3-dependent production of antiviral IFNs in the CNS during primary infection with HSV-1. However, they also suggested that the TRIF-dependent TLR4 and, probably, the DExD/H-box helicase pathways are largely redundant in host defense in humans. Like AR and AD TRIF deficiencies, AD TRAF3 deficiency was found to be associated with a relatively broad cellular phenotype, but a narrow clinical phenotype, in another patient with isolated childhood HSE [150]. TRAF3 functions downstream from multiple TNF receptors as well as receptors inducing IFN- $\alpha,-\beta$, and $-\lambda$ production, including TLR3 [79,151-154]. AD TRAF3 deficiency has been identified in a young adult with a history of HSE in childhood. The mutant TRAF3 allele in this patient is a loss-ofexpression, loss-of-function, dominant-negative mutant allele associated with impaired, but not abolished, TRAF3-dependent responses upon stimulation of both TNF receptors and receptors inducing IFN production, including TLR3 and cytosolic dsRNA sensors [150]. However, the clinical phenotype of this TRAF3-deficient patient was limited to HSE, presumably resulting from impairment of the TLR3-dependent induction of IFN in the CNS in the course of HSV-1 infection. The relatively broad cellular phenotype but narrow clinical phenotype (HSE) in patients with TRIF and TRAF3 deficiencies further implicated TLR3 in immunity to HSV-1 in the CNS.

The identification of AD TBK1 deficiency as a new genetic etiology of isolated childhood HSE was probably the greatest surprise to come out of human studies to date [14]. TBK1 is a kinase at the crossroads of multiple IFN-inducing signaling pathways, including those mediated by TLR3, cytosolic dsRNA sensors and dsDNA sensors [75,76,155]. Two unrelated children with HSE were found to carry different heterozygous mutations in the gene encoding TBK1. Both mutations are underlie a dominant phenotype, but presumably by different mechanisms: negative dominance or haplotype insufficiency. A defect in poly(I:C)-induced TLR3 responses could be detected only in fibroblasts from the patient carrying the dominant-negative TBK1 mutation. Nevertheless, levels of viral replication and cell death due to two TLR3-dependent viruses (HSV-1 and VSV) were high in fibroblasts from both patients. However, the PBMCs and fibroblasts from both patients displayed normal IFN responses to the TLR3-independent agonists and viruses tested [14]. AD TBK1 deficiency therefore confers narrow, partial cellular phenotypes, probably accounting for the narrow clinical phenotype of these patients, which is limited to HSE. Overall, the five genetic etiologies of HSE, with mutations in TLR3, UNC93B1, TRIF, TRAF3 and TBK1, have a similar cellular phenotype, consisting of impaired TLR3 signaling in fibroblasts, itself resulting in abnormally weak IFN $-\beta$ and $-\lambda$ production, enhanced viral replication and cell death in patients' cells, following infection with HSV-1 and VSV. The patients with these inborn errors of TLR3 immunity present no other viral diseases, or HSV-1 infections outside the CNS. Moreover, the clinical penetrance of these gene defects is incomplete. The viral phenotypes in the patients' fibroblasts were rescued by treatment with exogenous IFN$a,-\beta$, and, to a lesser extent, IFN- $\lambda$. These findings, together with the previous observation of the development of HSE in combination with mycobacterial disease in patients with AR complete STAT1 deficiency and X-linked NEMO deficiency [156-159], strongly suggest that human TLR3- and IFN-mediated immunity is essential for defense against HSV-1 in the CNS during primary infection in childhood, but apparently otherwise largely redundant in host defense.

Childhood HSE is not accompanied by the dissemination of HSV-1 disease via the bloodstream or epithelium or by other severe viral infections. Consistent with this clinical feature, most types of TLR3-expressing cells from AD or AR TLR3-deficient patients display a normal IFN response to poly(I:C) or HSV-1, including leukocytes in particular. This suggests that TLR3-independent or residual TLR3-dependent signaling in such cell types may contribute to antiviral immunity $[13,118]$. The human TLR3-IFN- $\alpha,-\beta$ and $-\lambda$ 
circuit therefore seems to confer selective protective immunity to HSV-1 in the CNS. The data for fibroblasts in vitro first provided a plausible mechanism for the pathogenesis of HSE in vivo in the CNS $[12,13]$, where TLR3 is indeed expressed and can stimulate IFN production, particularly in neurons, astrocytes, oligodendrocytes and microglial cells $[52,53,160,161]$. These CNS cells have all been shown to be permissive for HSV-1 infection in vitro [52,162-164]. The hypothesis that HSE pathogenesis in patients with inborn errors of TLR3 deficiencies involves CNS-specific, non hematopoietic resident cells was recently tested, by deriving induced pluripotent stem cells (iPSCs) from patients with TLR3 pathway deficiencies or from healthy controls [165]. UNC-93B- and TLR3-deficient neurons and oligodendrocytes were much more susceptible to HSV-1 infection than control cells, due to the lack of TLR3-dependent production of IFN- $\beta$ and IFN- $\lambda$. By contrast to the high degree of vulnerability of astrocytes to HSV-2 infection in TLR3-deficient mice [9], in vitro differentiated UNC-93B-deficient astrocytes or neural stem cells (NSCs) were no more susceptible to infection than control cells. However, human astrocytes and NSCs may play a role in protective anti-HSV-1 immunity in the CNS in vivo. These findings provided a cellular basis for the pathogenesis of childhood HSE in human patients with inborn errors of TLR3 immunity, involving impaired CNS-intrinsic TLR3-dependent IFN- $\alpha / \beta$ and IFN- $\lambda$ immunity to HSV-1[165] (Figure 2).

\section{Concluding remarks and perspectives}

Consistent with its high degree of conservation across vertebrate species [3] and its distinctive signature of purifying selection in humans [4,15], TLR3 is the only TLR to date that has been shown to play a non redundant role in host defense in both mice and humans. TLR3 is essential for host defense in mice, at least under some experimental conditions and against some viruses, and under natural conditions in humans, at least in some individuals, for protection of the CNS against HSV-1 during primary infection. Human studies have taught us that human TLR3 immunity is essential for protective intrinsic immunity to HSV-1 primary infection in the CNS, but otherwise largely redundant in host defense. Most human TLR3 pathway deficiencies seem to confer a relatively narrow predisposition to viruses, limited to HSE in the patients identified to date [16]. Exceptionally, one recently reported TLR3-deficient patient developed CVB3 myocarditis as an adult, which is consistent with the vulnerability of TLR3-deficient mice to related viruses [124,126]. There may be other, as yet unknown viral phenotypes to be discovered in TLR3-deficient patients. It is still too soon to draw definitive conclusions regarding the range of clinical phenotypes associated with TLR3 pathway deficiencies, given the limited number of patients identified and studied to date. It will be interesting to search for mutations in TLR3-IFN pathway genes in patients with HSE and other viral diseases, particularly those affecting other TLR3-expressing organs. Such studies should provide us with a broader vision of TLR3 protective immunity in natural conditions of infection.

Regardless of the specific role of human TLR3 in host defense against viruses, which will be defined more precisely as more patients are discovered, the redundancy of TLR3 is understandable, as it is not the only receptor that recognizes dsRNA. Several known cytosolic dsRNA sensors, including protein kinase R [166], 2'-5'-oligoadenylate synthetases [167], and the more recently identified RNA helicases RIG-I (retinoic acid-inducible gene I) and MDA5 (melanoma differentiation-associated gene 5), also recognize dsRNA and have been shown to confer distinct antiviral activity in studies carried out in vitro and in vivo in mice $[17-19,168,169]$. Other IFN-inducing pathways, including those mediated by the cytosolic dsDNA sensors DAI and IFI16 [170-172], may also contribute to host antiviral immunity. It is still largely unknown whether the multiple antiviral pathways are redundant with each other in host immunity to infections. TLR3 differs from the IFN-inducing cytosolic dsRNA or dsDNA sensors in terms of its ligand specificity, its unique cellular 
distribution and downstream signaling pathway, and these differences may govern a unique mechanism in host defense. Intriguingly, the clinical penetrance of human TLR3 pathway deficiencies was found to be incomplete even for HSE, as some HSV-1-infected genetically affected relatives have not developed HSE, perhaps due to diverse environmental, pathogenrelated (such as viral infection load and, less likely, virus strains), or host factors (age at infection, modifying genes, etc). This, in turn, paradoxically implies that although TLR3 function is life-saving in at least some individuals, it may be largely redundant in host defense in most individuals, and that HSE may be an uncommon event even among TLR3deficient patients. This makes determination of the precise clinical penetrance of TLR3 pathway deficiencies for HSE all the more important.

\section{Acknowledgments}

We would like to thank the past and present members of both branches of the Laboratory of Human Genetics of Infectious Diseases, and our collaborators on HSE, for the human studies discussed in this paper, particularly Emmanuelle Jouanguy, Fabien G Lafaille, Itai Pessach, Lorenz Studer and Luigi D Notarangelo. We also thank our colleagues for helpful discussions and critical reading of this manuscript. We warmly thank our patients, their families and physicians. The work was funded by grant number 8UL1TR000043 from the National Center for Translational Sciences (NCATS), National Institutes of Health (NIH), the Rockefeller University, the St. Giles Foundation, the ANR, INSERM, Paris Descartes University, the March of Dimes, the Thrasher Research Fund, Jeffrey Modell Foundation and Talecris Biotherapeutics, and NIH grants 5R01AI088364-02 and 5R01NS072381-02.

\section{References}

1. Bell JK, Mullen GE, Leifer CA, Mazzoni A, Davies DR, Segal DM. Leucine-rich repeats and pathogen recognition in Toll-like receptors. Trends Immunol. 2003; 24:528-533. [PubMed: 14552836]

2. Leulier F, Lemaitre B. Toll-like receptors--taking an evolutionary approach. Nat Rev Genet. 2008; 9:165-178. [PubMed: 18227810]

3*. Mikami T, Miyashita H, Takatsuka S, Kuroki Y, Matsushima N. Molecular evolution of vertebrate Toll-like receptors: evolutionary rate difference between their leucine-rich repeats and their TIR domains. Gene. 2012; 503:235-243. A paper reporting an intensive comparison of vertebrate TLRs, for the LRR and TIR domains of 366 vertebrates from 96 species. This is an interesting molecular evolutionary study of vertebrate TLRs. [PubMed: 22587897]

4. Barreiro LB, Ben-Ali M, Quach H, Laval G, Patin E, Pickrell JK, Bouchier C, Tichit M, Neyrolles $\mathrm{O}$, Gicquel B, et al. Evolutionary dynamics of human Toll-like receptors and their different contributions to host defense. PLoS Genet. 2009; 5:e1000562. [PubMed: 19609346]

5. Meylan E, Tschopp J. Toll-like receptors and RNA helicases: two parallel ways to trigger antiviral responses. Mol Cell. 2006; 22:561-569. [PubMed: 16762830]

6. Beutler B, Jiang Z, Georgel P, Crozat K, Croker B, Rutschmann S, Du X, Hoebe K. Genetic analysis of host resistance: Toll-like receptor signaling and immunity at large. Annu Rev Immunol. 2006; 24:353-389. [PubMed: 16551253]

7. Jacobs BL, Langland JO. When two strands are better than one: the mediators and modulators of the cellular responses to double-stranded RNA. Virology. 1996; 219:339-349. [PubMed: 8638399]

8. Tabeta K, Georgel P, Janssen E, Du X, Hoebe K, Crozat K, Mudd S, Shamel L, Sovath S, Goode J, et al. Toll-like receptors 9 and 3 as essential components of innate immune defense against mouse cytomegalovirus infection. Proc Natl Acad Sci USA. 2004; 101:3516-3521. [PubMed: 14993594]

9*. Reinert LS, Harder L, Holm CK, Iversen MB, Horan KA, Dagnaes-Hansen F, Ulhoi BP, Holm TH, Mogensen TH, Owens T, et al. TLR3 deficiency renders astrocytes permissive to herpes simplex virus infection and facilitates establishment of CNS infection in mice. J Clin Invest. 2012; 122:1368-1376. TLR3-deficient mice are susceptible to HSV-2 infection in the CNS. The cellular and molecular basis of this phenotype is associated with defective HSV-2-induced type I IFN production in astrocytes. [PubMed: 22426207]

10. Akira S, Uematsu S, Takeuchi O. Pathogen recognition and innate immunity. Cell. 2006; 124:783801. [PubMed: 16497588] 
$11^{*}$. Kawai T, Akira S. Toll-like receptors and their crosstalk with other innate receptors in infection and immunity. Immunity. 2011; 34:637-650. This review summarizes infectious pathogen recognition by TLRs, and discusses the interplay between TLRs and non TLR pattern recognition receptors. Host innate immunity is therefore sophisticated and complex. [PubMed: 21616434]

12. Zhang SY, Jouanguy E, Ugolini S, Smahi A, Elain G, Romero P, Segal D, Sancho-Shimizu V, Lorenzo L, Puel A, et al. TLR3 deficiency in patients with herpes simplex encephalitis. Science. 2007; 317:1522-1527. [PubMed: 17872438]

13. Casrouge A, Zhang SY, Eidenschenk C, Jouanguy E, Puel A, Yang K, Alcais A, Picard C, Mahfoufi N, Nicolas N, et al. Herpes simplex virus encephalitis in human UNC-93B deficiency. Science. 2006; 314:308-312. [PubMed: 16973841]

14**. Herman M, Ciancanelli M, Ou YH, Lorenzo L, Klaudel-Dreszler M, Pauwels E, SanchoShimizu V, Perez de Diego R, Abhyankar A, Israelsson E, et al. Heterozygous TBK1 mutations impair TLR3 immunity and underlie herpes simplex encephalitis of childhood. J Exp Med. 2012; 209:1567-82. This paper reports autosomal dominant TBK1 deficiency as a new genetic etiology of childhood herpes simplex encephalitis. Heterozygous missense mutations in TBK1, encoding a kinase at the crossroads of multiple IFN-inducing signaling pathways, lead to a narrow, partial cellular phenotype, with impaired TLR3-dependent IFN responses to HSV-1, which explains the clinical phenotype of these patients being limited to HSE. [PubMed: 22851595]

15**. Casanova JL, Abel L, Quintana-Murci L. Human TLRs and IL-1Rs in host defense: natural insights from evolutionary, epidemiological, and clinical genetics. Annu Rev Immunol. 2011; 29:447-91. A comprehensive review of the role of human TLRs and IL-Rs in host defense, from the available evidence in evolutionary, epidemiological and clinical genetics. [PubMed: 21219179]

16. Sancho-Shimizu V, de Diego RP, Jouanguy E, Zhang SY, Casanova JL. Inborn errors of anti-viral interferon immunity in humans. Curr Opin Virol. 2011; 1:487-496. [PubMed: 22347990]

17. Yoneyama M, Kikuchi M, Natsukawa T, Shinobu N, Imaizumi T, Miyagishi M, Taira K, Akira S, Fujita T. The RNA helicase RIG-I has an essential function in double-stranded RNA-induced innate antiviral responses. Nat Immunol. 2004; 5:730-737. [PubMed: 15208624]

18. Kato H, Takeuchi O, Sato S, Yoneyama M, Yamamoto M, Matsui K, Uematsu S, Jung A, Kawai T, Ishii KJ, et al. Differential roles of MDA5 and RIG-I helicases in the recognition of RNA viruses. Nature. 2006; 441:101-105. [PubMed: 16625202]

19. Pichlmair A, Schulz O, Tan CP, Naslund TI, Liljestrom P, Weber F, Reis e Sousa C. RIG-Imediated antiviral responses to single-stranded RNA bearing 5'-phosphates. Science. 2006; 314:997-1001. [PubMed: 17038589]

20. Choe J, Kelker MS, Wilson IA. Crystal structure of human toll-like receptor 3 (TLR3) ectodomain. Science. 2005; 309:581-585. [PubMed: 15961631]

21. Bell JK, Botos I, Hall PR, Askins J, Shiloach J, Segal DM, Davies DR. The molecular structure of the Toll-like receptor 3 ligand-binding domain. Proc Natl Acad Sci USA. 2005; 102:10976-10980. [PubMed: 16043704]

22. Bell JK, Askins J, Hall PR, Davies DR, Segal DM. The dsRNA binding site of human Toll-like receptor 3. Proc Natl Acad Sci USA. 2006; 103:8792-8797. [PubMed: 16720699]

23. de Bouteiller O, Merck E, Hasan UA, Hubac S, Benguigui B, Trinchieri G, Bates EE, Caux C. Recognition of double-stranded RNA by human toll-like receptor 3 and downstream receptor signaling requires multimerization and an acidic pH. J Biol Chem. 2005; 280:38133-38145. [PubMed: 16144834]

24. Ranjith-Kumar CT, Miller W, Xiong J, Russell WK, Lamb R, Santos J, Duffy KE, Cleveland L, Park M, Bhardwaj K, et al. Biochemical and functional analyses of the human Toll-like receptor 3 ectodomain. J Biol Chem. 2007; 282:7668-7678. [PubMed: 17209042]

25. Takada E, Okahira S, Sasai M, Funami K, Seya T, Matsumoto M. C-terminal LRRs of human Tolllike receptor 3 control receptor dimerization and signal transmission. Mol Immunol. 2007; 44:3633-3640. [PubMed: 17521732]

26. Liu L, Botos I, Wang Y, Leonard JN, Shiloach J, Segal DM, Davies DR. Structural basis of tolllike receptor 3 signaling with double-stranded RNA. Science. 2008; 320:379-381. [PubMed: 18420935] 
27. Leonard JN, Ghirlando R, Askins J, Bell JK, Margulies DH, Davies DR, Segal DM. The TLR3 signaling complex forms by cooperative receptor dimerization. Proc Natl Acad Sci USA. 2008; 105:258-263. [PubMed: 18172197]

28. Pirher N, Ivicak K, Pohar J, Bencina M, Jerala R. A second binding site for double-stranded RNA in TLR3 and consequences for interferon activation. Nat Struct Mol Biol. 2008; 15:761-763. [PubMed: 18568036]

29. Botos I, Liu L, Wang Y, Segal DM, Davies DR. The toll-like receptor 3:dsRNA signaling complex. Biochim Biophys Acta. 2009; 1789:667-674. [PubMed: 19595807]

30*. Wang Y, Liu L, Davies DR, Segal DM. Dimerization of Toll-like receptor 3 (TLR3) is required for ligand binding. J Biol Chem. 2010; 285:36836-36841. The most recent paper reporting the essential role of TLR3 dimerization. A precise receptor-ligand complex is proposed in this paper. [PubMed: 20861016]

31. Okahira S, Nishikawa F, Nishikawa S, Akazawa T, Seya T, Matsumoto M. Interferon-beta induction through toll-like receptor 3 depends on double-stranded RNA structure. DNA Cell Biol. 2005; 24:614-623. [PubMed: 16225392]

32. Alexopoulou L, Holt AC, Medzhitov R, Flavell RA. Recognition of double-stranded RNA and activation of NF-kappaB by Toll-like receptor 3. Nature. 2001; 413:732-738. [PubMed: 11607032]

33. Kariko K, Ni H, Capodici J, Lamphier M, Weissman D. mRNA is an endogenous ligand for Tolllike receptor 3. J Biol Chem. 2004; 279:12542-12550. [PubMed: 14729660]

34. Cavassani KA, Ishii M, Wen H, Schaller MA, Lincoln PM, Lukacs NW, Hogaboam CM, Kunkel SL. TLR3 is an endogenous sensor of tissue necrosis during acute inflammatory events. J Exp Med. 2008; 205:2609-2621. [PubMed: 18838547]

35*. Bernard JJ, Cowing-Zitron C, Nakatsuji T, Muehleisen B, Muto J, Borkowski AW, Martinez L, Greidinger EL, Yu BD, Gallo RL. Ultraviolet radiation damages self noncoding RNA and is detected by TLR3. Nat Med. 2012; 8:1286-1290. By a combination of in vitro and in vivo studies, this paper demonstrates that ultraviolet radiation damages cell self noncoding snU1 RNA, which is detected by TLR3. These results suggest a role for TLR3 in determining the outcome of UVB exposure.

36. Kariko K, Buckstein M, Ni H, Weissman D. Suppression of RNA recognition by Toll-like receptors: the impact of nucleoside modification and the evolutionary origin of RNA. Immunity. 2005; 23:165-175. [PubMed: 16111635]

37. Kadowaki N, Ho S, Antonenko S, Malefyt RW, Kastelein RA, Bazan F, Liu YJ. Subsets of human dendritic cell precursors express different toll-like receptors and respond to different microbial antigens. J Exp Med. 2001; 194:863-869. [PubMed: 11561001]

38. Tabiasco J, Devevre E, Rufer N, Salaun B, Cerottini JC, Speiser D, Romero P. Human effector CD8+ T lymphocytes express TLR3 as a functional coreceptor. J Immunol. 2006; 177:8708-8713. [PubMed: 17142772]

39. Schmidt KN, Leung B, Kwong M, Zarember KA, Satyal S, Navas TA, Wang F, Godowski PJ. APC-independent activation of NK cells by the Toll-like receptor 3 agonist double-stranded RNA. J Immunol. 2004; 172:138-143. [PubMed: 14688319]

40. Kumar MV, Nagineni CN, Chin MS, Hooks JJ, Detrick B. Innate immunity in the retina: Toll-like receptor (TLR) signaling in human retinal pigment epithelial cells. J Neuroimmunol. 2004; 153:715. [PubMed: 15265658]

41. Sun J, Duffy KE, Ranjith-Kumar CT, Xiong J, Lamb RJ, Santos J, Masarapu H, Cunningham M, Holzenburg A, Sarisky RT, et al. Structural and functional analyses of the human Toll-like receptor 3. Role of glycosylation. J Biol Chem. 2006; 281:11144-11151. [PubMed: 16533755]

42. Harada K, Sato Y, Itatsu K, Isse K, Ikeda H, Yasoshima M, Zen Y, Matsui A, Nakanuma Y. Innate immune response to double-stranded RNA in biliary epithelial cells is associated with the pathogenesis of biliary atresia. Hepatology. 2007; 46:1146-1154. [PubMed: 17661372]

43. Nakamura M, Funami K, Komori A, Yokoyama T, Aiba Y, Araki A, Takii Y, Ito M, Matsuyama M, Koyabu M, et al. Increased expression of Toll-like receptor 3 in intrahepatic biliary epithelial cells at sites of ductular reaction in diseased livers. Hepatol Int. 2008; 2:222-230. [PubMed: 19669308] 
44. Cario E, Podolsky DK. Differential alteration in intestinal epithelial cell expression of toll-like receptor 3 (TLR3) and TLR4 in inflammatory bowel disease. Infect Immun. 2000; 68:7010-7017. [PubMed: 11083826]

45. Tohyama M, Dai X, Sayama K, Yamasaki K, Shirakata Y, Hanakawa Y, Tokumaru S, Yahata Y, Yang L, Nagai H, et al. dsRNA-mediated innate immunity of epidermal keratinocytes. Biochem Biophys Res Commun. 2005; 335:505-511. [PubMed: 16087162]

46. Lebre MC, van der Aar AM, van Baarsen L, van Capel TM, Schuitemaker JH, Kapsenberg ML, de Jong EC. Human keratinocytes express functional Toll-like receptor 3, 4, 5, and 9. J Invest Dermatol. 2007; 127:331-341. [PubMed: 17068485]

47. Matsumoto M, Kikkawa S, Kohase M, Miyake K, Seya T. Establishment of a monoclonal antibody against human Toll-like receptor 3 that blocks double-stranded RNA-mediated signaling. Biochem Biophys Res Commun. 2002; 293:1364-1369. [PubMed: 12054664]

48. Zimmer S, Steinmetz M, Asdonk T, Motz I, Coch C, Hartmann E, Barchet W, Wassmann S, Hartmann G, Nickenig G. Activation of endothelial toll-like receptor 3 impairs endothelial function. Circ Res. 2011; 108:1358-1366. [PubMed: 21493895]

49. Wang N, Liang Y, Devaraj S, Wang J, Lemon SM, Li K. Toll-like receptor 3 mediates establishment of an antiviral state against hepatitis C virus in hepatoma cells. J Virol. 2009; 83:9824-9834. [PubMed: 19625408]

50. Bsibsi M, Ravid R, Gveric D, van Noort JM. Broad expression of Toll-like receptors in the human central nervous system. J Neuropathol Exp Neurol. 2002; 61:1013-1021. [PubMed: 12430718]

51. Jackson AC, Rossiter JP, Lafon M. Expression of Toll-like receptor 3 in the human cerebellar cortex in rabies, herpes simplex encephalitis, and other neurological diseases. J Neurovirol. 2006; 12:229-234. [PubMed: 16877304]

52. Prehaud C, Megret F, Lafage M, Lafon M. Virus infection switches TLR-3-positive human neurons to become strong producers of beta interferon. J Virol. 2005; 79:12893-12904. [PubMed: 16188991]

53. Jack CS, Arbour N, Manusow J, Montgrain V, Blain M, McCrea E, Shapiro A, Antel JP. TLR signaling tailors innate immune responses in human microglia and astrocytes. J Immunol. 2005; 175:4320-4330. [PubMed: 16177072]

54. McKimmie CS, Johnson N, Fooks AR, Fazakerley JK. Viruses selectively upregulate Toll-like receptors in the central nervous system. Biochem Biophys Res Commun. 2005; 336:925-933. [PubMed: 16157304]

55. McCartney S, Vermi W, Gilfillan S, Cella M, Murphy TL, Schreiber RD, Murphy KM, Colonna M. Distinct and complementary functions of MDA5 and TLR3 in poly(I:C)-mediated activation of mouse NK cells. J Exp Med. 2009; 206:2967-2976. [PubMed: 19995959]

56. Perrot I, Deauvieau F, Massacrier C, Hughes N, Garrone P, Durand I, Demaria O, Viaud N, Gauthier L, Blery M, et al. TLR3 and Rig-like receptor on myeloid dendritic cells and Rig-like receptor on human NK cells are both mandatory for production of IFN-gamma in response to double-stranded RNA. J Immunol. 2010; 185:2080-2088. [PubMed: 20639488]

57. Kumar A, Zhang J, Yu FS. Toll-like receptor 3 agonist poly(I:C)-induced antiviral response in human corneal epithelial cells. Immunology. 2006; 117:11-21. [PubMed: 16423036]

58. Lebre MC, van der Aar AM, van Baarsen L, van Capel TM, Schuitemaker JH, Kapsenberg ML, de Jong EC. Human keratinocytes express functional Toll-like receptor 3, 4, 5, and 9. J Invest Dermatol. 2007; 127:331-341. [PubMed: 17068485]

59. Bsibsi M, Persoon-Deen C, Verwer RW, Meeuwsen S, Ravid R, Van Noort JM. Toll-like receptor 3 on adult human astrocytes triggers production of neuroprotective mediators. Glia. 2006; 53:688695. [PubMed: 16482523]

60. Tabeta K, Hoebe K, Janssen EM, Du X, Georgel P, Crozat K, Mudd S, Mann N, Sovath S, Goode $\mathrm{J}$, et al. The Unc93b1 mutation 3d disrupts exogenous antigen presentation and signaling via Tolllike receptors 3, 7 and 9. Nat Immunol. 2006; 7:156-164. [PubMed: 16415873]

61. Brinkmann MM, Spooner E, Hoebe K, Beutler B, Ploegh HL, Kim YM. The interaction between the ER membrane protein UNC93B and TLR3, 7, and 9 is crucial for TLR signaling. J Cell Biol. 2007; 177:265-275. [PubMed: 17452530] 
62. Kim YM, Brinkmann MM, Paquet ME, Ploegh HL. UNC93B1 delivers nucleotide-sensing tolllike receptors to endolysosomes. Nature. 2008; 452:234-238. [PubMed: 18305481]

63. Johnsen IB, Nguyen TT, Ringdal M, Tryggestad AM, Bakke O, Lien E, Espevik T, Anthonsen MW. Toll-like receptor 3 associates with c-Src tyrosine kinase on endosomes to initiate antiviral signaling. EMBO J. 2006; 25:3335-3346. [PubMed: 16858407]

64*. Yamashita M, Chattopadhyay S, Fensterl V, Saikia P, Wetzel JL, Sen GC. Epidermal growth factor receptor is essential for Toll-like receptor 3 signaling. Sci Signal. 2012; 5:ra50. A paper reporting a biochemical demonstration of TLR3 phosphorylation by EGFR and SRC. [PubMed: 22810896]

65. Sun H, Zhuang G, Chai L, Wang Z, Johnson D, Ma Y, Chen YH. TIPE2 controls innate immunity to RNA by targeting the phosphatidylinositol 3-kinase-Rac pathway. J Immunol. 2012; 189:27682773. [PubMed: 22904303]

66. Sarkar SN, Peters KL, Elco CP, Sakamoto S, Pal S, Sen GC. Novel roles of TLR3 tyrosine phosphorylation and PI3 kinase in double-stranded RNA signaling. Nat Struct Mol Biol. 2004; 11:1060-1067. [PubMed: 15502848]

67. Oshiumi H, Matsumoto M, Funami K, Akazawa T, Seya T. TICAM-1, an adaptor molecule that participates in Toll-like receptor 3-mediated interferon-beta induction. Nat Immunol. 2003; 4:161167. [PubMed: 12539043]

68. Yamamoto M, Sato S, Hemmi H, Hoshino K, Kaisho T, Sanjo H, Takeuchi O, Sugiyama M, Okabe M, Takeda K, et al. Role of adaptor TRIF in the MyD88-independent toll-like receptor signaling pathway. Science. 2003; 301:640-643. [PubMed: 12855817]

69. Akira S, Takeda K. Toll-like receptor signalling. Nat Rev Immunol. 2004; 4:499-511. [PubMed: 15229469]

70. O'Neill LA, Bowie AG. The family of five: TIR-domain-containing adaptors in Toll-like receptor signalling. Nat Rev Immunol. 2007; 7:353-364. [PubMed: 17457343]

71. Han KJ, Su X, Xu LG, Bin LH, Zhang J, Shu HB. Mechanisms of the TRIF-induced interferonstimulated response element and NF-kappaB activation and apoptosis pathways. J Biol Chem. 2004; 279:15652-15661. [PubMed: 14739303]

72. Kaiser WJ, Offermann MK. Apoptosis induced by the toll-like receptor adaptor TRIF is dependent on its receptor interacting protein homotypic interaction motif. J Immunol. 2005; 174:4942-4952. [PubMed: 15814722]

73. Ruckdeschel K, Pfaffinger G, Haase R, Sing A, Weighardt H, Hacker G, Holzmann B, Heesemann J. Signaling of apoptosis through TLRs critically involves toll/IL-1 receptor domain-containing adapter inducing IFN-beta, but not MyD88, in bacteria-infected murine macrophages. J Immunol. 2004; 173:3320-3328. [PubMed: 15322195]

74. Doyle S, Vaidya S, O’Connell R, Dadgostar H, Dempsey P, Wu T, Rao G, Sun R, Haberland M, Modlin R, et al. IRF3 mediates a TLR3/TLR4-specific antiviral gene program. Immunity. 2002; 17:251-263. [PubMed: 12354379]

75. Fitzgerald KA, McWhirter SM, Faia KL, Rowe DC, Latz E, Golenbock DT, Coyle AJ, Liao SM, Maniatis T. IKKepsilon and TBK1 are essential components of the IRF3 signaling pathway. Nat Immunol. 2003; 4:491-496. [PubMed: 12692549]

76. McWhirter SM, Fitzgerald KA, Rosains J, Rowe DC, Golenbock DT, Maniatis T. IFN-regulatory factor 3-dependent gene expression is defective in Tbk1-deficient mouse embryonic fibroblasts. Proc Natl Acad Sci USA. 2004; 101:233-238. [PubMed: 14679297]

77. Sasai M, Oshiumi H, Matsumoto M, Inoue N, Fujita F, Nakanishi M, Seya T. Cutting Edge: NFkappaB-activating kinase-associated protein 1 participates in TLR3/Toll-IL-1 homology domaincontaining adapter molecule-1-mediated IFN regulatory factor 3 activation. J Immunol. 2005; 174:27-30. [PubMed: 15611223]

78. Hacker H, Redecke V, Blagoev B, Kratchmarova I, Hsu LC, Wang GG, Kamps MP, Raz E, Wagner H, Hacker G, et al. Specificity in Toll-like receptor signalling through distinct effector functions of TRAF3 and TRAF6. Nature. 2006; 439:204-207. [PubMed: 16306937]

79. Oganesyan G, Saha SK, Guo B, He JQ, Shahangian A, Zarnegar B, Perry A, Cheng G. Critical role of TRAF3 in the Toll-like receptor-dependent and -independent antiviral response. Nature. 2006; 439:208-211. [PubMed: 16306936] 
80. Meylan E, Burns K, Hofmann K, Blancheteau V, Martinon F, Kelliher M, Tschopp J. RIP1 is an essential mediator of Toll-like receptor 3-induced NF-kappa B activation. Nat Immunol. 2004; 5:503-507. [PubMed: 15064760]

81. Gohda J, Matsumura T, Inoue J. Cutting edge: TNFR-associated factor (TRAF) 6 is essential for MyD88-dependent pathway but not toll/IL-1 receptor domain-containing adaptor-inducing IFNbeta (TRIF)-dependent pathway in TLR signaling. J Immunol. 2004; 173:2913-2917. [PubMed: 15322147]

82. Sato S, Sugiyama M, Yamamoto M, Watanabe Y, Kawai T, Takeda K, Akira S. Toll/IL-1 receptor domain-containing adaptor inducing IFN-beta (TRIF) associates with TNF receptor-associated factor 6 and TANK-binding kinase 1, and activates two distinct transcription factors, NF-kappa B and IFN-regulatory factor-3, in the Toll-like receptor signaling. J Immunol. 2003; 171:4304-4310. [PubMed: 14530355]

83. Jiang Z, Zamanian-Daryoush M, Nie H, Silva AM, Williams BR, Li X. Poly(I-C)-induced Tolllike receptor 3 (TLR3)-mediated activation of NFkappa B and MAP kinase is through an interleukin-1 receptor-associated kinase (IRAK)-independent pathway employing the signaling components TLR3-TRAF6-TAK1-TAB2-PKR. J Biol Chem. 2003; 278:16713-16719. [PubMed: 12609980]

84. Shim JH, Xiao C, Paschal AE, Bailey ST, Rao P, Hayden MS, Lee KY, Bussey C, Steckel M, Tanaka N, et al. TAK1, but not TAB1 or TAB2, plays an essential role in multiple signaling pathways in vivo. Genes Dev. 2005; 19:2668-2681. [PubMed: 16260493]

$85^{*}$. Israel A. The IKK complex, a central regulator of NF-kappaB activation. Cold Spring Harb Perspect Biol. 2010:a000158. A comprehensive review of the IKK complex. [PubMed: 20300203]

86. Takaki H, Oshiumi H, Sasai M, Kawanishi T, Matsumoto M, Seya T. Oligomerized TICAM-1 (TRIF) in the cytoplasm recruits nuclear BS69 to enhance NF-kappaB activation and type I IFN induction. Eur J Immunol. 2009; 39:3469-3476. [PubMed: 19795416]

87*. Sasai M, Tatematsu M, Oshiumi H, Funami K, Matsumoto M, Hatakeyama S, Seya T. Direct binding of TRAF2 and TRAF6 to TICAM-1/TRIF adaptor participates in activation of the Tolllike receptor 3/4 pathway. Mol Immunol. 2010; 47:1283-1291. This paper places TRAF2 and TRAF6 in the TLR3-TRIF signalosome. [PubMed: 20047764]

88*. Chang CH, Lai LC, Cheng HC, Chen KR, Syue YZ, Lu HC, Lin WY, Chen SH, Huang HS, Shiau AL, et al. TBK1-associated protein in endolysosomes (TAPE) is an innate immune regulator modulating the TLR3 and TLR4 signaling pathways. J Biol Chem. 2011; 286:70437051. This paper demonstrates that TAPE is associated with TRIF. It may therefore play an important role in TLR3 signaling. [PubMed: 21189260]

89*. Carpenter S, Wochal P, Dunne A, O'Neill LA. Toll-like receptor 3 (TLR3) signaling requires TLR4 interactor with leucine-rich repeats (TRIL). J Biol Chem. 2011; 286:38795-38804. This paper shows that TRIL co-localizes with endosomal compartment. It interacts with TLR3 as an accessory molecule and is required for TLR3 signaling. [PubMed: 21911501]

90. Chariot A, Leonardi A, Muller J, Bonif M, Brown K, Siebenlist U. Association of the adaptor TANK with the I kappa B kinase (IKK) regulator NEMO connects IKK complexes with IKK epsilon and TBK1 kinases. J Biol Chem. 2002; 277:37029-37036. [PubMed: 12133833]

91. Guo B, Cheng G. Modulation of the interferon antiviral response by the TBK1/IKKi adaptor protein TANK. J Biol Chem. 2007; 282:11817-11826. [PubMed: 17327220]

92. Ryzhakov G, Randow F. SINTBAD, a novel component of innate antiviral immunity, shares a TBK1-binding domain with NAP1 and TANK. EMBO J. 2007; 26:3180-3190. [PubMed: 17568778]

93. Ermolaeva MA, Michallet MC, Papadopoulou N, Utermohlen O, Kranidioti K, Kollias G, Tschopp J, Pasparakis M. Function of TRADD in tumor necrosis factor receptor 1 signaling and in TRIFdependent inflammatory responses. Nat Immunol. 2008; 9:1037-1046. [PubMed: 18641654]

94. Pobezinskaya YL, Kim YS, Choksi S, Morgan MJ, Li T, Liu C, Liu Z. The function of TRADD in signaling through tumor necrosis factor receptor 1 and TRIF-dependent Toll-like receptors. Nat Immunol. 2008; 9:1047-1054. [PubMed: 18641653]

95. Soulat D, Burckstummer T, Westermayer S, Goncalves A, Bauch A, Stefanovic A, Hantschel O, Bennett KL, Decker T, Superti-Furga G. The DEAD-box helicase DDX3X is a critical component 
of the TANK-binding kinase 1-dependent innate immune response. EMBO J. 2008; 27:21352146. [PubMed: 18583960]

96. Liu X, Yao M, Li N, Wang C, Zheng Y, Cao X. CaMKII promotes TLR-triggered proinflammatory cytokine and type I interferon production by directly binding and activating TAK1 and IRF3 in macrophages. Blood. 2008; 112:4961-4970. [PubMed: 18818394]

97*. Watanabe A, Tatematsu M, Saeki K, Shibata S, Shime H, Yoshimura A, Obuse C, Seya T, Matsumoto M. Raftlin is involved in the nucleocapture complex to induce poly(I:C)-mediated TLR3 activation. J Biol Chem. 2011; 286:10702-10711. This paper demonstrates that the cytoplasmic lipid raft protein, Raftlin, is essential for poly(I:C) cellular uptake in human myeloid dendritic cells and epithelial cells, directing poly(I:C) to TLR3-positive endosomes. Raftlin is therefore critical for activation of TLR3. [PubMed: 21266579]

98. Zheng Y, An H, Yao M, Hou J, Yu Y, Feng G, Cao X. Scaffolding adaptor protein Gab1 is required for TLR3/4- and RIG-I-mediated production of proinflammatory cytokines and type I IFN in macrophages. J Immunol. 2010; 184:6447-6456. [PubMed: 20435932]

99. Yanai H, Ban T, Wang Z, Choi MK, Kawamura T, Negishi H, Nakasato M, Lu Y, Hangai S, Koshiba R, et al. HMGB proteins function as universal sentinels for nucleic-acid-mediated innate immune responses. Nature. 2009; 462:99-103. [PubMed: 19890330]

100. Yang K, Shi HX, Liu XY, Shan YF, Wei B, Chen S, Wang C. TRIM21 is essential to sustain IFN regulatory factor 3 activation during antiviral response. J Immunol. 2009; 182:3782-3792. [PubMed: 19265157]

101. Pulkkinen V, Bruce S, Rintahaka J, Hodgson U, Laitinen T, Alenius H, Kinnula VL, Myllarniemi M, Matikainen S, Kere J. ELMOD2, a candidate gene for idiopathic pulmonary fibrosis, regulates antiviral responses. FASEB J. 2010; 24:1167-1177. [PubMed: 19966137]

102*. Shen Y, Li NL, Wang J, Liu B, Lester S, Li K. TRIM56 is an essential component of the TLR3 antiviral signaling pathway. J Biol Chem. 2012 [Epub ahead of print]. The most recent paper reporting experimental evidence for the identification of an additional component of the TLR3 pathway (TRIM56).

103. Yew KH, Carsten B, Harrison C. Scavenger receptor A1 is required for sensing HCMV by endosomal TLR-3/-9 in monocytic THP-1 cells. Mol Immunol. 2009; 47:883-893. [PubMed: 19914718]

104. Han KJ, Yang Y, Xu LG, Shu HB. Analysis of a TIR-less splice variant of TRIF reveals an unexpected mechanism of TLR3-mediated signaling. J Biol Chem. 2010; 285:12543-12550. [PubMed: 20200155]

105. Higgs R, Ni Gabhann J, Ben Larbi N, Breen EP, Fitzgerald KA, Jefferies CA. The E3 ubiquitin ligase Ro52 negatively regulates IFN-beta production post-pathogen recognition by polyubiquitin-mediated degradation of IRF3. J Immunol. 2008; 181:1780-1786. [PubMed: 18641315]

106. Chang M, Jin W, Sun SC. Peli1 facilitates TRIF-dependent Toll-like receptor signaling and proinflammatory cytokine production. Nat Immunol. 2009; 10:1089-1095. [PubMed: 19734906]

107. An H, Zhao W, Hou J, Zhang Y, Xie Y, Zheng Y, Xu H, Qian C, Zhou J, Yu Y, et al. SHP-2 phosphatase negatively regulates the TRIF adaptor protein-dependent type I interferon and proinflammatory cytokine production. Immunity. 2006; 25:919-928. [PubMed: 17157040]

108. Su X, Li S, Meng M, Qian W, Xie W, Chen D, Zhai Z, Shu HB. TNF receptor-associated factor-1 (TRAF1) negatively regulates Toll/IL-1 receptor domain-containing adaptor inducing IFN-beta (TRIF)-mediated signaling. Eur J Immunol. 2006; 36:199-206. [PubMed: 16323247]

109. Takeshita F, Ishii KJ, Kobiyama K, Kojima Y, Coban C, Sasaki S, Ishii N, Klinman DM, Okuda $\mathrm{K}$, Akira S, et al. TRAF4 acts as a silencer in TLR-mediated signaling through the association with TRAF6 and TRIF. Eur J Immunol. 2005; 35:2477-2485. [PubMed: 16052631]

110. Boone DL, Turer EE, Lee EG, Ahmad RC, Wheeler MT, Tsui C, Hurley P, Chien M, Chai S, Hitotsumatsu O, et al. The ubiquitin-modifying enzyme A20 is required for termination of Tolllike receptor responses. Nat Immunol. 2004; 5:1052-1060. [PubMed: 15334086]

111. Saitoh T, Yamamoto M, Miyagishi M, Taira K, Nakanishi M, Fujita T, Akira S, Yamamoto N, Yamaoka S. A20 is a negative regulator of IFN regulatory factor 3 signaling. J Immunol. 2005; 174:1507-1512. [PubMed: 15661910] 
112. Carty M, Goodbody R, Schroder M, Stack J, Moynagh PN, Bowie AG. The human adaptor SARM negatively regulates adaptor protein TRIF-dependent Toll-like receptor signaling. Nat Immunol. 2006; 7:1074-1081. [PubMed: 16964262]

113. Zhang J, Xu LG, Han KJ, Wei X, Shu HB. PIASy represses TRIF-induced ISRE and NF-kappaB activation but not apoptosis. FEBS Lett. 2004; 570:97-101. [PubMed: 15251447]

114. Huang J, Liu T, Xu LG, Chen D, Zhai Z, Shu HB. SIKE is an IKK epsilon/TBK1-associated suppressor of TLR3- and virus-triggered IRF-3 activation pathways. EMBO J. 2005; 24:40184028. [PubMed: 16281057]

115. Zhang M, Wang L, Zhao X, Zhao K, Meng H, Zhao W, Gao C. TRAF-interacting protein (TRIP) negatively regulates IFN-beta production and antiviral response by promoting proteasomal degradation of TANK-binding kinase 1. J Exp Med. 2012; 209:1703-1711. [PubMed: 22945920]

116. Kayagaki N, Phung Q, Chan S, Chaudhari R, Quan C, O’Rourke KM, Eby M, Pietras E, Cheng $\mathrm{G}$, Bazan JF, et al. DUBA: a deubiquitinase that regulates type I interferon production. Science. 2007; 318:1628-1632. [PubMed: 17991829]

117. Zhao T, Yang L, Sun Q, Arguello M, Ballard DW, Hiscott J, Lin R. The NEMO adaptor bridges the nuclear factor-kappaB and interferon regulatory factor signaling pathways. Nat Immunol. 2007; 8:592-600. [PubMed: 17468758]

118**. Guo Y, Audry M, Ciancanelli M, Alsina L, Azevedo J, Herman M, Anguiano E, SanchoShimizu V, Lorenzo L, Pauwels E, et al. Herpes simplex virus encephalitis in a patient with complete TLR3 deficiency: TLR3 is otherwise redundant in protective immunity. J Exp Med. 2011; 208:2083-2098. This is the first description of autosomal ressive, complete TLR3 deficiency in humans. The genetic data and immunological data demonstrate that human TLR3 is essential against primary HSV-1 infection in the CNS of at least some patients, while it is largely redundant in protective immunity against other infections. [PubMed: 21911422]

119. Itan Y, Zhang SY, Vogt G, Quintana-Murci L, Abel L, Casanova JL. The human gene connectome: A map of short cuts for morbid allele discovery. 2012 Submitted for publication.

120*. Li S, Wang L, Berman M, Kong YY, Dorf ME. Mapping a dynamic innate immunity protein interaction network regulating type I interferon production. Immunity. 2011; 35:426-440. A study demonstrating the power of proteomic approaches to mapping innate immune signaling networks. [PubMed: 21903422]

121. Zhang Z, Kim T, Bao M, Facchinetti V, Jung SY, Ghaffari AA, Qin J, Cheng G, Liu YJ. DDX1, DDX21, and DHX36 helicases form a complex with the adaptor molecule TRIF to sense dsRNA in dendritic cells. Immunity. 2011; 34:866-878. [PubMed: 21703541]

122. Hardarson HS, Baker JS, Yang Z, Purevjav E, Huang CH, Alexopoulou L, Li N, Flavell RA, Bowles NE, Vallejo JG. Toll-like receptor 3 is an essential component of the innate stress response in virus-induced cardiac injury. Am J Physiol Heart Circ Physiol. 2007; 292:H251-258. [PubMed: 16936008]

123*. McCartney SA, Vermi W, Lonardi S, Rossini C, Otero K, Calderon B, Gilfillan S, Diamond MS, Unanue ER, Colonna M. RNA sensor-induced type I IFN prevents diabetes caused by a beta cell-tropic virus in mice. J Clin Invest. 2011; 121:1497-1507. This paper reports on the infection of a pancreatic $\beta$ cell-tropic EMCV in TLR3-deficient mice, in comparison with MDA5-deficient and wild type mice. This study suggests that infection of TLR3-deficient mice causes diabetes due to impaired type I IFN responses and virus induced $\beta$ cell damage. [PubMed: 21403398]

124. Negishi H, Osawa T, Ogami K, Ouyang X, Sakaguchi S, Koshiba R, Yanai H, Seko Y, Shitara H, Bishop K, et al. A critical link between Toll-like receptor 3 and type II interferon signaling pathways in antiviral innate immunity. Proc Natl Acad Sci USA. 2008; 105:20446-20451. [PubMed: 19074283]

125. Abston ED, Coronado MJ, Bucek A, Bedja D, Shin J, Kim JB, Kim E, Gabrielson KL, Georgakopoulos D, Mitzner W, et al. Th2 regulation of viral myocarditis in mice: different roles for TLR3 versus TRIF in progression to chronic disease. Clin Dev Immunol. 2012:129486. [PubMed: 22013485]

126. Richer MJ, Lavallee DJ, Shanina I, Horwitz MS. Toll-like receptor 3 signaling on macrophages is required for survival following coxsackievirus B4 infection. PLoS ONE. 2009; 4:e4127.

[PubMed: 19122812] 
127*. Abe Y, Fujii K, Nagata N, Takeuchi O, Akira S, Oshiumi H, Matsumoto M, Seya T, Koike S. The toll-like receptor 3-mediated antiviral response is important for protection against poliovirus infection in poliovirus receptor transgenic mice. J Virol. 2012; 86:185-194. This paper demonstrates that the TLR3-TRIF-mediated pathway is essential for protective immunity against poliovirus. [PubMed: 22072781]

128. Oshiumi H, Okamoto M, Fujii K, Kawanishi T, Matsumoto M, Koike S, Seya T. The TLR3/ TICAM-1 pathway is mandatory for innate immune responses to poliovirus infection. J Immunol. 2011; 187:5320-5327. [PubMed: 21998457]

129*. Davey GM, Wojtasiak M, Proietto AI, Carbone FR, Heath WR, Bedoui S. Cutting edge: priming of CD8 T cell immunity to herpes simplex virus type 1 requires cognate TLR3 expression in vivo. J Immunol. 2010; 184:2243-2246. This paper reports on the cutaneous HSV-1 infection in TLR3-deficient mice. High viral loads were detected at the site of inoculation in those mice. [PubMed: 20124105]

130. Rudd BD, Smit JJ, Flavell RA, Alexopoulou L, Schaller MA, Gruber A, Berlin AA, Lukacs NW. Deletion of TLR3 alters the pulmonary immune environment and mucus production during respiratory syncytial virus infection. J Immunol. 2006; 176:1937-1942. [PubMed: 16424225]

131. Edelmann KH, Richardson-Burns S, Alexopoulou L, Tyler KL, Flavell RA, Oldstone MB. Does Toll-like receptor 3 play a biological role in virus infections? Virology. 2004; 322:231-238. [PubMed: 15110521]

132*. Jin YH, Kaneyama T, Kang MH, Kang HS, Koh CS, Kim BS. TLR3 signaling is either protective or pathogenic for the development of Theiler's virus-induced demyelinating disease depending on the time of viral infection. J Neuroinflammation. 2011; 8:178. A study of TMEV infection in TLR3-deficient mice, in which direct comparisons are made between different viral strains and between different mouse strains, in terms of infectious phenotypes. Different degrees of susceptibility are observed when different strains of TLR3-deficient mice or different strains of TMEV are used. [PubMed: 22189096]

133. Le Goffic R, Balloy V, Lagranderie M, Alexopoulou L, Escriou N, Flavell R, Chignard M, SiTahar M. Detrimental contribution of the Toll-like receptor (TLR)3 to influenza A virus-induced acute pneumonia. PLoS Pathog. 2006; 2:e53. [PubMed: 16789835]

134. Gowen B, Hoopes JD, Wong MH, Jung KH, Isakson KC, Alexopoulou L, Flavell RA, Sidwell RW. TLR3 deletion limits mortality and disease severity due to Phlebovirus infection. J Immunol. 2006; 177:6301-6307. [PubMed: 17056560]

135. Hutchens M, Luker KE, Sottile P, Sonstein J, Lukacs NW, Nunez G, Curtis JL, Luker GD. TLR3 increases disease morbidity and mortality from vaccinia infection. J Immunol. 2008; 180:483491. [PubMed: 18097050]

136. Wang T, Town T, Alexopoulou L, Anderson JF, Fikrig E, Flavell RA. Toll-like receptor 3 mediates West Nile virus entry into the brain causing lethal encephalitis. Nat Med. 2004; 10:1366-1373. [PubMed: 15558055]

137. Whitley RJ, Kimberlin DW. Herpes simplex encephalitis: children and adolescents. Semin Pediatr Infect Dis. 2005; 16:17-23. [PubMed: 15685145]

138. Whitley RJ. Herpes simplex encephalitis: adolescents and adults. Antiviral Res. 2006; 71:141148. [PubMed: 16675036]

139. Jacquemont B, Roizman B. RNA synthesis in cells infected with herpes simplex virus. X. Properties of viral symmetric transcripts and of double-stranded RNA prepared from them. J Virol. 1975; 15:707-713. [PubMed: 163916]

140. Weber F, Wagner V, Rasmussen SB, Hartmann R, Paludan SR. Double-stranded RNA is produced by positive-strand RNA viruses and DNA viruses but not in detectable amounts by negative-strand RNA viruses. J Virol. 2006; 80:5059-5064. [PubMed: 16641297]

141*. Abel L, Plancoulaine S, Jouanguy E, Zhang SY, Mahfoufi N, Nicolas N, Sancho-Shimizu V, Alcais A, Guo Y, Cardon A, et al. Age-dependent Mendelian predisposition to herpes simplex virus type 1 encephalitis in childhood. J Pediatr. 2010; 157:623-629. A comprehensive epidemiological study of childhood HSE. This study demonstrated that host susceptibility to HSE is age-dependent, supporting the notion that Mendelian gene defects underlie childhood HSE. [PubMed: 20553844] 
142. Ku CL, Yang K, Bustamante J, Puel A, von Bernuth H, Santos OF, Lawrence T, Chang HH, AlMousa H, Picard C, et al. Inherited disorders of human Toll-like receptor signaling: immunological implications. Immunol Rev. 2005; 203:10-20. [PubMed: 15661018]

143. von Bernuth H, Picard C, Jin Z, Pankla R, Xiao H, Ku CL, Chrabieh M, Mustapha IB, Ghandil P, Camcioglu Y, et al. Pyogenic bacterial infections in humans with MyD88 deficiency. Science. 2008; 321:691-696. [PubMed: 18669862]

144. Zhang SY, Jouanguy E, Sancho-Shimizu V, von Bernuth H, Yang K, Abel L, Picard C, Puel A, Casanova JL. Human Toll-like receptor-dependent induction of interferons in protective immunity to viruses. Immunol Rev. 2007; 220:225-236. [PubMed: 17979850]

145. Yang K, Puel A, Zhang S, Eidenschenk C, Ku CL, Casrouge A, Picard C, von Bernuth H, Senechal B, Plancoulaine S, et al. Human TLR-7-, -8-, and -9-mediated induction of IFN-alpha/ beta and -lambda Is IRAK-4 dependent and redundant for protective immunity to viruses. Immunity. 2005; 23:465-478. [PubMed: 16286015]

146. Ku CL, von Bernuth H, Picard C, Zhang SY, Chang HH, Yang K, Chrabieh M, Issekutz AC, Cunningham CK, Gallin J, et al. Selective predisposition to bacterial infections in IRAK-4deficient children: IRAK-4-dependent TLRs are otherwise redundant in protective immunity. J Exp Med. 2007; 204:2407-2422. [PubMed: 17893200]

147. Quintana-Murci L, Alcais A, Abel L, Casanova JL. Immunology in natura: clinical, epidemiological and evolutionary genetics of infectious diseases. Nat Immunol. 2007; 8:11651171. [PubMed: 17952041]

148. Casanova JL, Abel L. Primary immunodeficiencies: a field in its infancy. Science. 2007; 317:617-619. [PubMed: 17673650]

149**. Sancho-Shimizu V, Perez de Diego R, Lorenzo L, Halwani R, Alangari A, Israelsson E, Fabrega S, Cardon A, Maluenda J, Tatematsu M, et al. Herpes simplex encephalitis in children with autosomal recessive and dominant TRIF deficiency. J Clin Invest. 2011; 121:4889-4902. This paper describes the first autosomal recessive and autosomal dominant forms of human TRIF deficiency. TRIF-deficient fibroblasts display impaired TLR3-dependent production of antiviral IFNs. TRIF-deficient patients display HSE, like TLR3-deficient patients. The TRIF-dependent TLR4 and DExD/H-box helicase pathways are thus largely redundant in humans. [PubMed: 22105173]

150**. Perez de Diego R, Sancho-Shimizu V, Lorenzo L, Puel A, Plancoulaine S, Picard C, Herman M, Cardon A, Durandy A, Bustamante J, et al. Human TRAF3 adaptor molecule deficiency leads to impaired Toll-like receptor 3 response and susceptibility to herpes simplex encephalitis. Immunity. 2010; 33:400-411. This paper reports autosomal dominant human TRAF3 deficiency. It is associated with a relatively broad cellular phenotype, with impaired responses to stimulation of multiple IFN-inducing pathways, including TLR3. The clinical phenotype is restricted to HSE, confirming that even a partial defect of TLR3 response is essential for immunity against HSV-1 in the CNS, and implying that residual IFN responses to receptors other than TLR3 are sufficient for protective immunity against other infections. [PubMed: 20832341]

151. Hoebe K, Beutler B. TRAF3: a new component of the TLR-signaling apparatus. Trends Mol Med. 2006; 12:187-189. [PubMed: 16621716]

152. Saha SK, Pietras EM, He JQ, Kang JR, Liu SY, Oganesyan G, Shahangian A, Zarnegar B, Shiba TL, Wang Y, et al. Regulation of antiviral responses by a direct and specific interaction between TRAF3 and Cardif. EMBO J. 2006; 25:3257-3263. [PubMed: 16858409]

153. Bishop GA, Xie P. Multiple roles of TRAF3 signaling in lymphocyte function. Immunol Res. 2007; 39:22-32. [PubMed: 17917053]

154. He JQ, Oganesyan G, Saha SK, Zarnegar B, Cheng G. TRAF3 and its biological function. Adv Exp Med Biol. 2007; 597:48-59. [PubMed: 17633016]

155. Chau TL, Gioia R, Gatot JS, Patrascu F, Carpentier I, Chapelle JP, O’Neill L, Beyaert R, Piette J, Chariot A. Are the IKKs and IKK-related kinases TBK1 and IKK-epsilon similarly activated? Trends Biochem Sci. 2008; 33:171-180. [PubMed: 18353649]

156. Dupuis S, Jouanguy E, Al-Hajjar S, Fieschi C, Al-Mohsen IZ, Al-Jumaah S, Yang K, Chapgier A, Eidenschenk C, Eid P, et al. Impaired response to interferon-alpha/beta and lethal viral disease in human STAT1 deficiency. Nat Genet. 2003; 33:388-391. [PubMed: 12590259] 
157. Niehues T, Reichenbach J, Neubert J, Gudowius S, Puel A, Horneff G, Lainka E, Dirksen U, Schroten H, Döffinger R, et al. A NEMO-deficient child with immunodeficiency yet without anhidrotic ectodermal dysplasia. J Allergy Clin Immunol. 2004; 114:1456-1462. [PubMed: 15577852]

158. Puel A, Reichenbach J, Bustamante J, Ku CL, Feinberg J, Doffinger R, Bonnet M, Filipe-Santos $\mathrm{O}$, Beaucoudrey L, Durandy A, et al. The NEMO mutation creating the most-upstream premature stop codon is hypomorphic because of a reinitiation of translation. Am J Hum Genet. 2006; 78:691-701. [PubMed: 16532398]

159. Audry M, Ciancanelli M, Yang K, Cobat A, Chang HH, Sancho-Shimizu V, Lorenzo L, Niehues T, Reichenbach J, Li XX, et al. NEMO is a key component of NF-kappaB- and IRF-3-dependent TLR3-mediated immunity to herpes simplex virus. J Allergy Clin Immunol. 2011; 128:610-617e611-614. [PubMed: 21722947]

160. Olson JK, Miller SD. Microglia initiate central nervous system innate and adaptive immune responses through multiple TLRs. J Immunol. 2004; 173:3916-3924. [PubMed: 15356140]

161. Rivieccio MA, Suh HS, Zhao Y, Zhao ML, Chin KC, Lee SC, Brosnan CF. TLR3 ligation activates an antiviral response in human fetal astrocytes: a role for viperin/cig5. J Immunol. 2006; 177:4735-4741. [PubMed: 16982913]

162. Mitchell BM, Bloom DC, Cohrs RJ, Gilden DH, Kennedy PG. Herpes simplex virus-1 and varicella-zoster virus latency in ganglia. J Neurovirol. 2003; 9:194-204. [PubMed: 12707850]

163. Bello-Morales R, Fedetz M, Alcina A, Tabares E, Lopez-Guerrero JA. High susceptibility of a human oligodendroglial cell line to herpes simplex type 1 infection. J Neurovirol. 2005; 11:190198. [PubMed: 16036797]

164. Marques CP, Hu S, Sheng W, Lokensgard JR. Microglial cells initiate vigorous yet nonprotective immune responses during HSV-1 brain infection. Virus Res. 2006; 121:1-10. [PubMed: 16621100]

165**. Lafaille FG, Pessach IM, Zhang SY, Ciancanelli MJ, Herman M, Mostoslavsky G, OrdovasMontanes J, Jouanguy E, Plancoulaine S, Tu E, et al. Impaired intrinsic immunity to HSV-1 in human iPSC-derived TLR3-deficient CNS cells. Nature. 2012 in press. This study has used patient-specific iPSC cells derived from dermal fibroblasts to obtain and test TLR3-deficient non-hematopoietic CNS cells, including neural stem cells, neurons, oligodendrocytes, and astrocytes. These cells are shown to rely on TLR3 to respond to dsRNA and to control HSV-1. The cellular basis of HSE in children with inborn errors of TLR3 immunity therefore involves non-hematopoietic CNS resident cells.

166. McAllister CS, Taghavi N, Samuel CE. Protein kinase PKR amplification of interferon beta induction occurs through initiation factor eIF-2alpha-mediated translational control. J Biol Chem. 2012 Epub ahead of print.

167. Malathi K, Paranjape JM, Bulanova E, Shim M, Guenther-Johnson JM, Faber PW, Eling TE, Williams BR, Silverman RH. A transcriptional signaling pathway in the IFN system mediated by 2'-5'-oligoadenylate activation of RNase L. Proc Natl Acad Sci USA. 2005; 102:14533-14538. [PubMed: 16203993]

168. Loo YM, Gale M Jr. Immune signaling by RIG-I-like receptors. Immunity. 2011; 34:680-692. [PubMed: 21616437]

169. Belgnaoui SM, Paz S, Hiscott J. Orchestrating the interferon antiviral response through the mitochondrial antiviral signaling (MAVS) adapter. Curr Opin Immunol. 2011; 23:564-572. [PubMed: 21865020]

170. Ishii KJ, Coban C, Kato H, Takahashi K, Torii Y, Takeshita F, Ludwig H, Sutter G, Suzuki K, Hemmi H, et al. A Toll-like receptor-independent antiviral response induced by double-stranded B-form DNA. Nat Immunol. 2006; 7:40-48. [PubMed: 16286919]

171. Okabe Y, Kawane K, Akira S, Taniguchi T, Nagata S. Toll-like receptor-independent gene induction program activated by mammalian DNA escaped from apoptotic DNA degradation. $\mathbf{J}$ Exp Med. 2005; 202:1333-1339. [PubMed: 16301743]

172. Stetson DB, Medzhitov R. Recognition of cytosolic DNA activates an IRF3-dependent innate immune response. Immunity. 2006; 24:93-103. [PubMed: 16413926] 


\section{Highlights}

1. Upon stimulation by dsRNA, TLR3 dimerizes and recruits TRIF, and the subsequent activation of IRF3 and NF- $\kappa$ B leads to induction of target genes.

2. TLR3-deficient mice and their wild-type (WT) littermates have been experimentally infected with 16 different viruses.

3. Consequences of TLR 3 deficiency in mice range from enhanced susceptibility to normal or even greater resistance to certain viruses than WT mice.

4. Some human patients with inborn errors of the TLR3 pathway develop herpes simplex virus 1 encephalitis during primary infection.

5. Human patients with inborn errors of the TLR 3 pathway are apparently normally resistant to most other infections, including viral infections. 


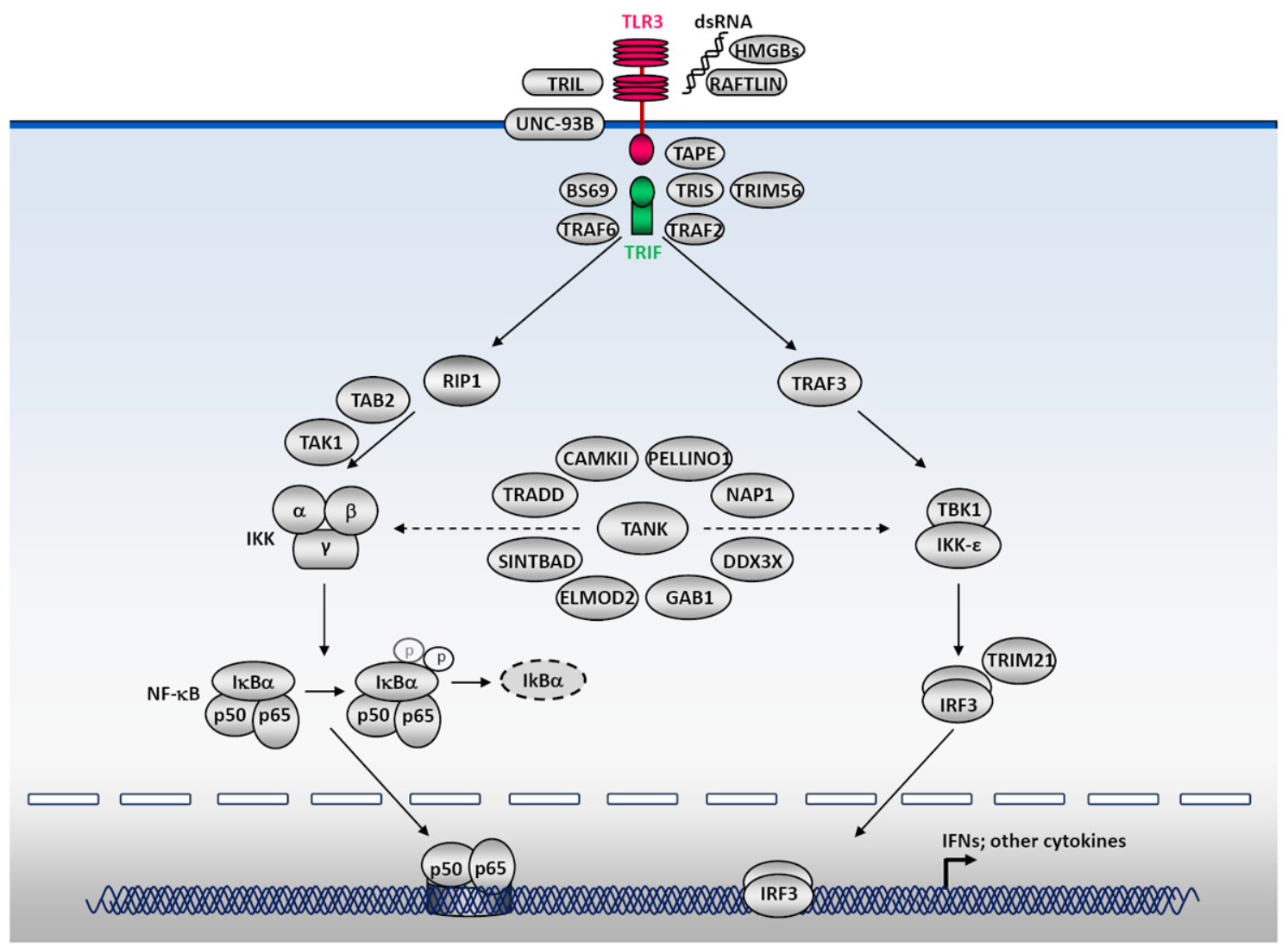

Figure 1. TLR3 signaling pathways leading to the activation of NF- $x$ B and IRF3

The TLR3 signaling pathway is mediated exclusively by the TRIF adapter. TLR3-TRIF interaction and the downstream signaling it induces lead to the activation of IRF3 and NF$\kappa \mathrm{B}$. The phosphorylation of IRF3 is mediated by two kinases, TBK1 and IKKe, which themselves associate with TRIF through a signalosome complex also containing other key molecules, including TRAF3. The activation of NF- $\kappa \mathrm{B}$ is thought to be essentially mediated by RIP1, and probably also by TRAF6 in some cell types. RIP1 and TRAF6 subsequently recruit TAB2 and TAK1, which phosphorylates IKKa and IKK $\beta$. These two kinases and the IKK adaptor protein IKK $\gamma$ (NEMO) form the IKK complex. IKK $\beta$, in turn, phosphorylates the NF- $\kappa \mathrm{B}$ inhibitor $\mathrm{I} \kappa \mathrm{B}$, eventually leading to its degradation and the nuclear translocation of NF- $\kappa$ B. Other molecules that have been experimentally implicated in the TLR3-IRF3/NFкB-IFN pathways are also indicated, including BS69, TAPE, TRAF2, TANK, TRIL, SINTBAD, TRADD, DDX3X, CaMKII, RAFLIN, GAB1, TRIM21, TRIM56, HMGB, ELMOD2, PELLINO1 and TRIS. The activation and nucleus translocation of IRF3 and NF$\mathrm{\kappa B}$ lead to the induction of antiviral IFNs and other cytokines. 


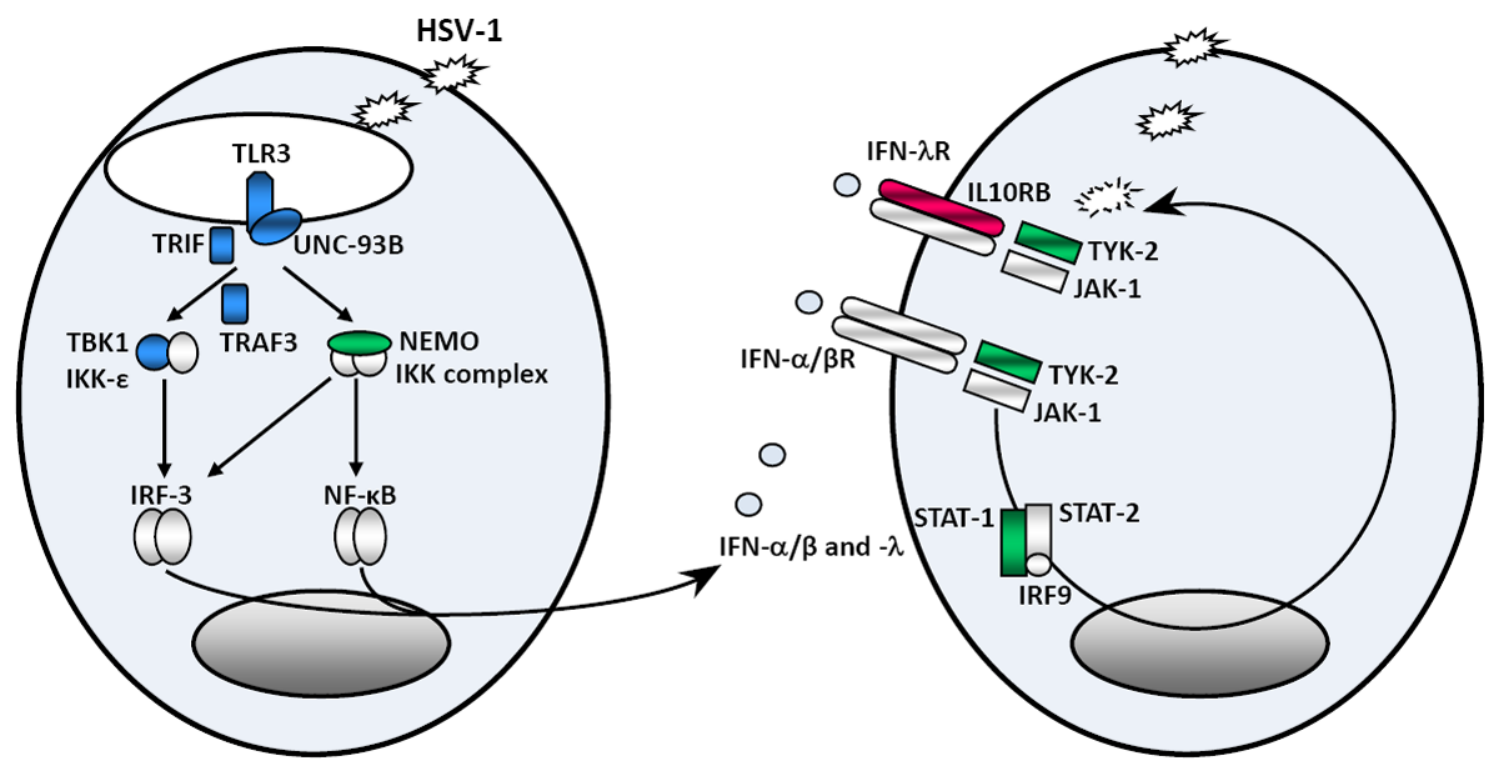

\section{Neurons/Oligodendrocytes/other CNS cells}

Figure 2. Inborn errors of TLR3-mediated and IFN-mediated immunity in childhood herpes simplex virus 1 encephalitis

Schematic representation of the production of and response to IFN- $\alpha / \beta$, and IFN- $\lambda$ in antiHSV-1 immunity. HSV-1 produces viral dsRNA during its replication. TLR3 is a transmembrane receptor of dsRNA in the endoplasmic reticulum and endosome. The recognition of dsRNA by TLR3 induces activation of the IRF-3 and NF-kB pathways via TRIF, leading to the production of IFN- $\alpha / \beta$ and/or IFN- $\lambda$. TLR3, UNC-93B, TRIF, TRAF3, TBK1 and NEMO deficiencies are associated with impaired IFN- $\alpha / \beta$ and/or IFN- $\lambda$ production, particularly during HSV-1 infection. The binding of IFN- $\alpha / \beta$ or IFN- $\lambda$ to its receptor induces the phosphorylation of JAK 1 and TYK-2, activating the signal transduction proteins STAT-1, STAT-2 and IRF9. This complex is translocated, as a heterotrimer, to the nucleus, where it acts as a transcriptional activator, binding to specific DNA response elements in the promoter region of IFN-inducible genes. STAT-1 and TYK2 deficiencies are associated with impaired IFN- $a,-\beta$ and $-\lambda$ responses. Proteins for which genetic mutations have been identified and associated with susceptibility to isolated HSE are shown in blue. Proteins for which genetic mutations have been identified and associated with susceptibility to mycobacterial, bacterial and viral diseases, including HSE, are shown in green. Proteins for which genetic mutations have been identified but not associated with susceptibility to viral diseases are shown in red. 

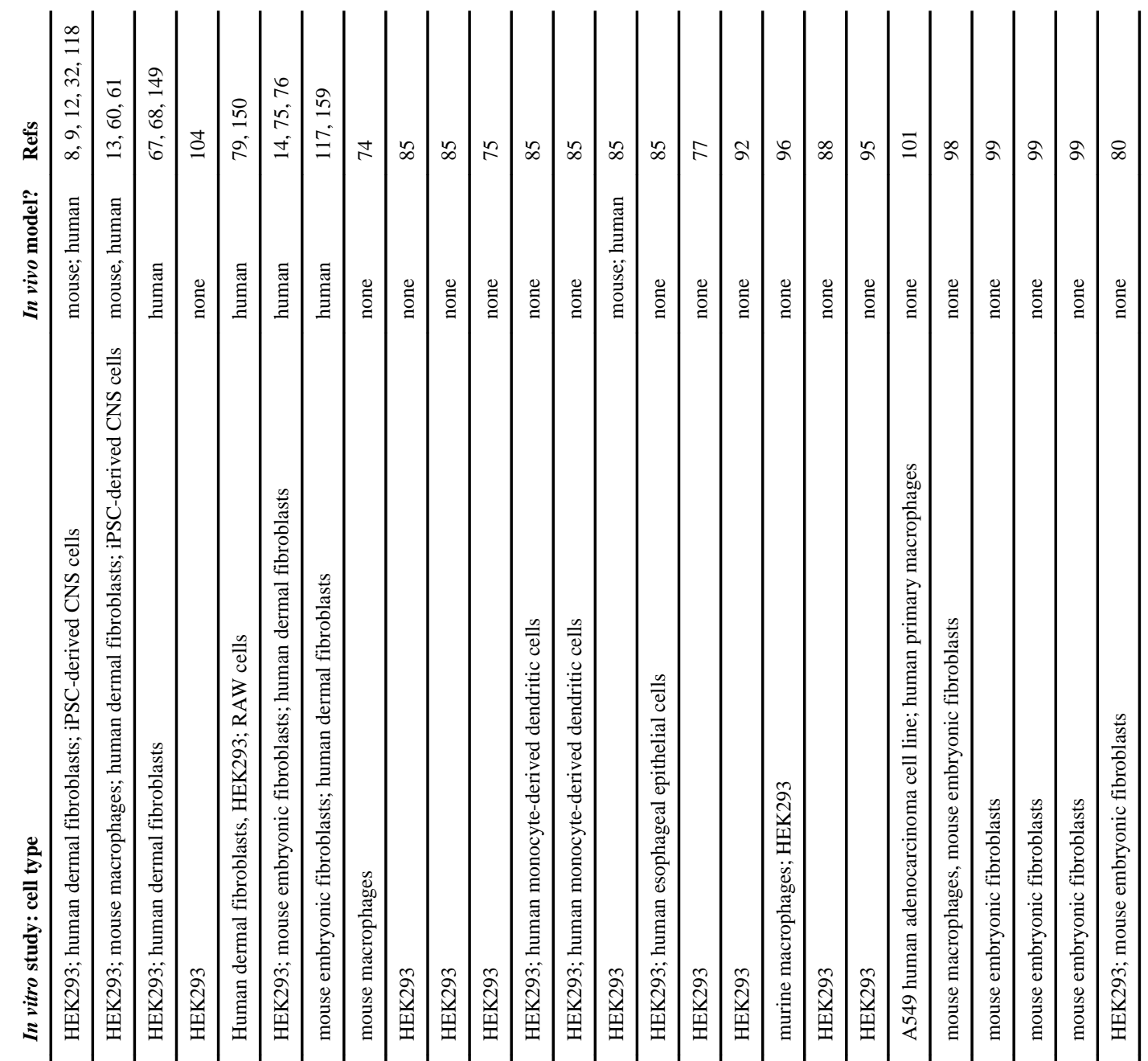

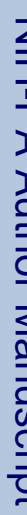

త

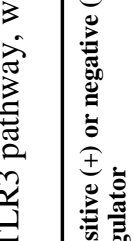

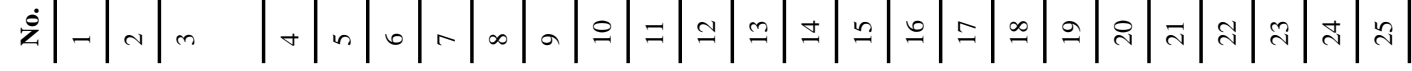




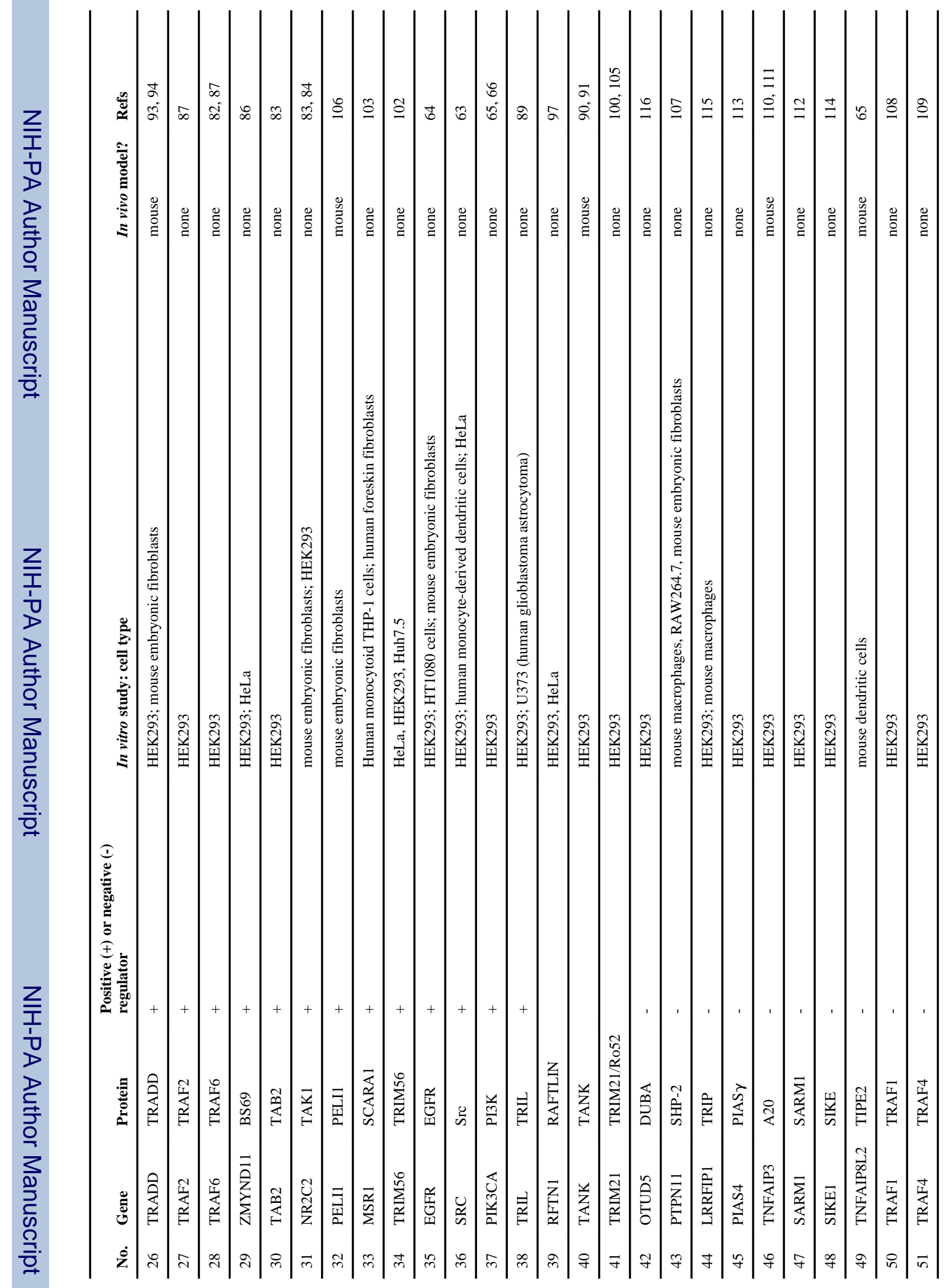




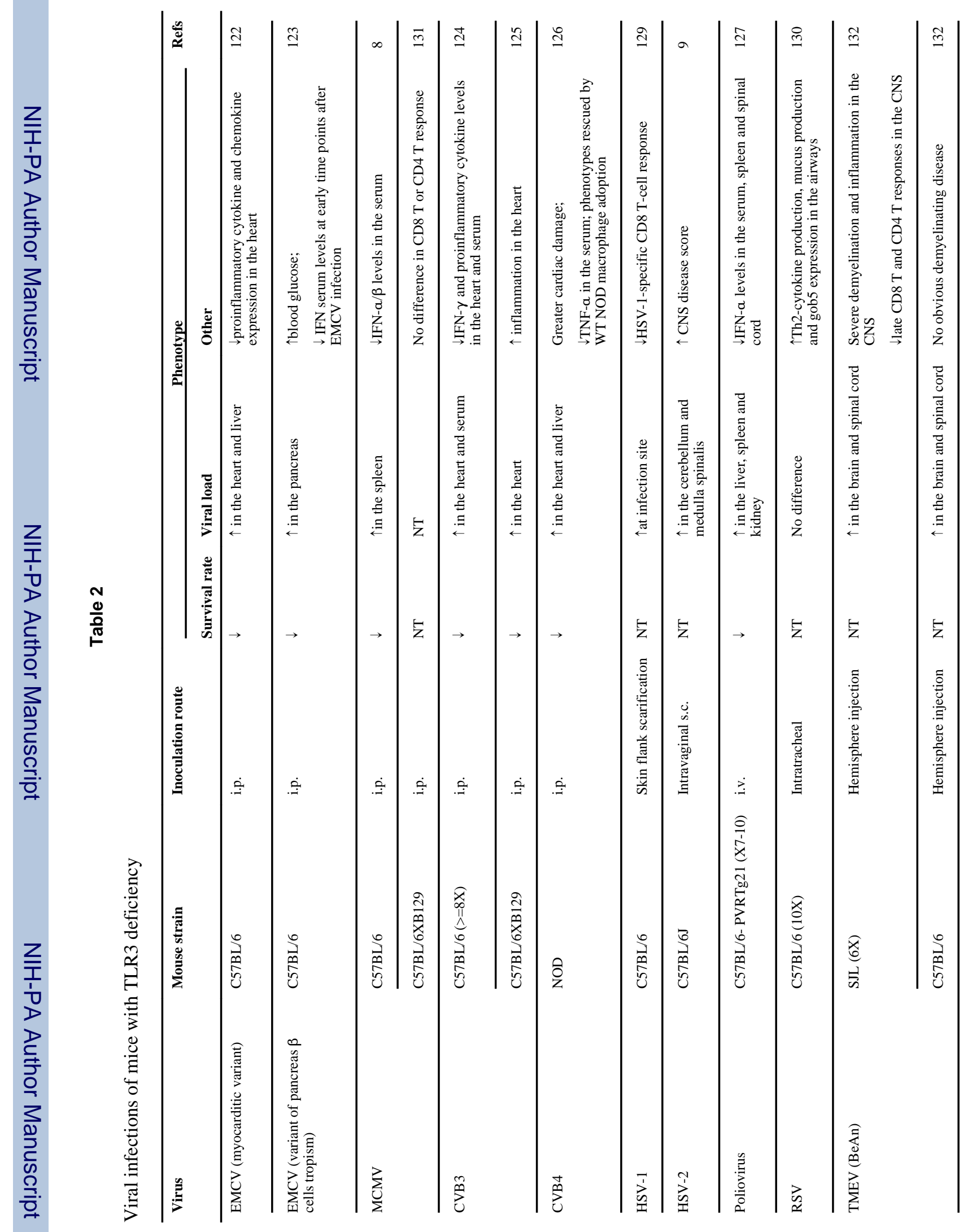




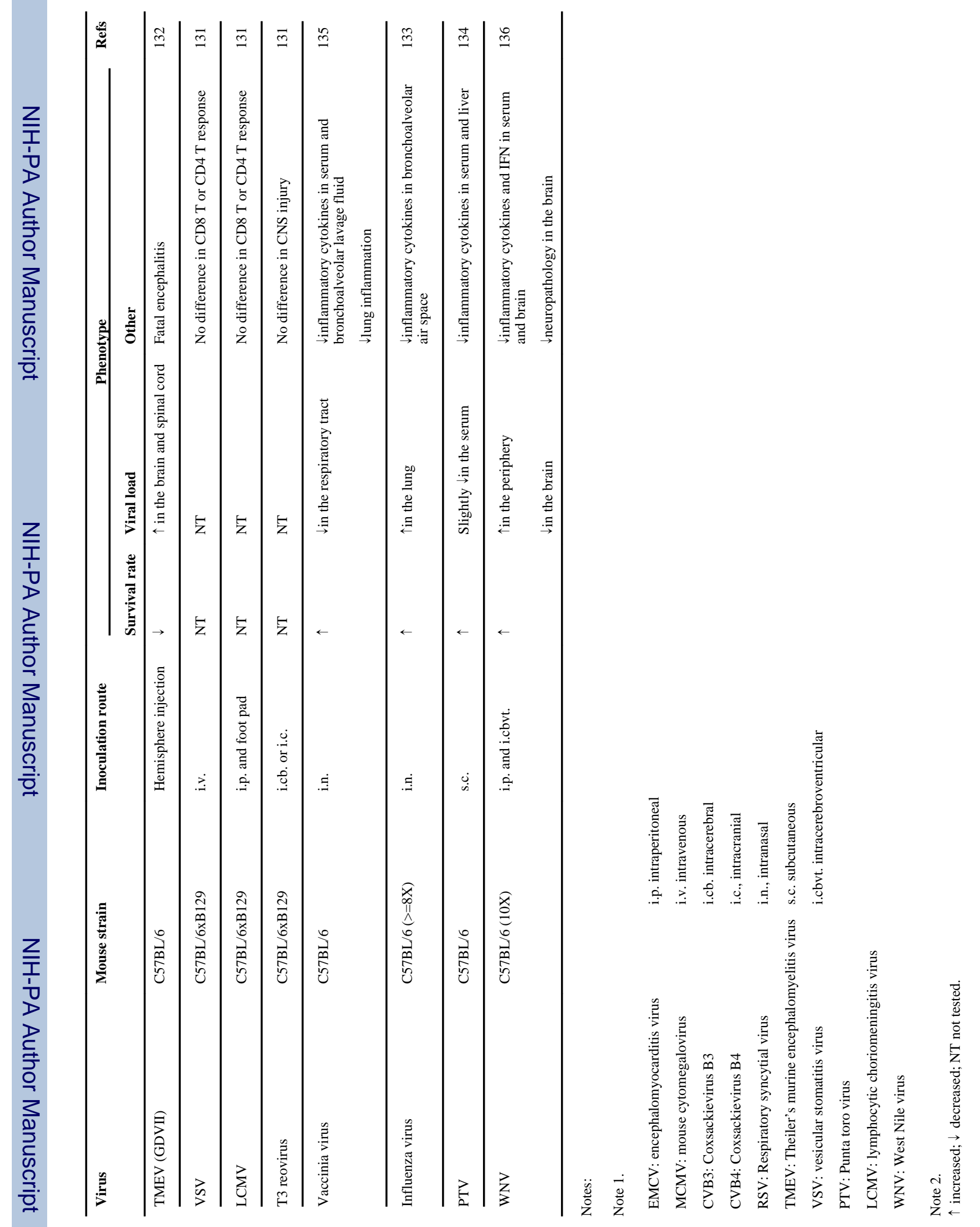


